\title{
A High-Fidelity Codon Set for the T4 DNA ligase-Catalyzed Polymerization of Modified Oligonucleotides
}

\author{
Yi Lei, Dehui Kong, Ryan Hili ${ }^{*}$ \\ Department of Chemistry, University of Georgia, 140 Cedar Street, Athens, Georgia 30602- \\ 2556, United States
}

Supporting Information

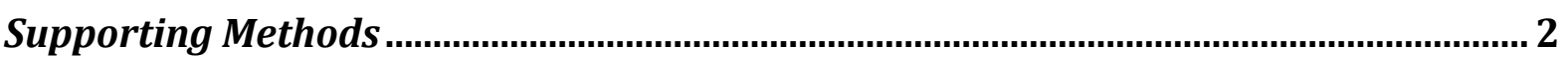

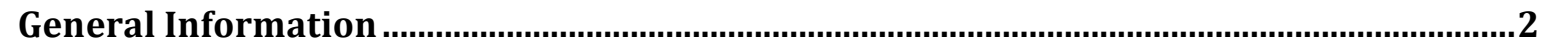

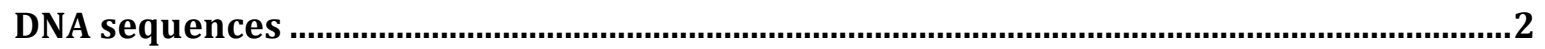

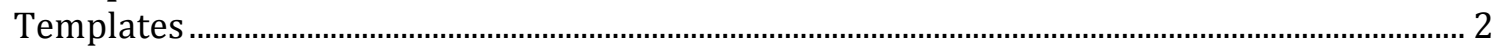

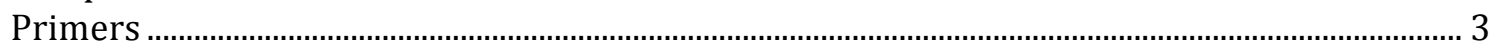

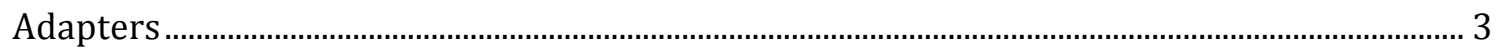

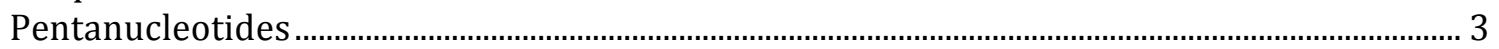

Synthesis of amino-modified pentanucleotides.......................................................................4

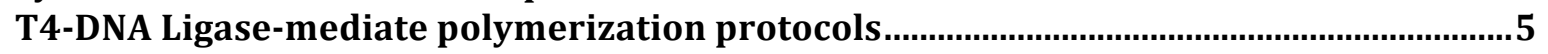

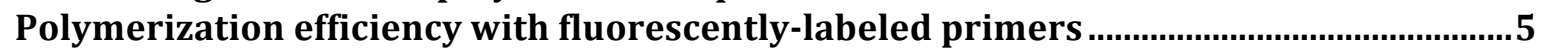

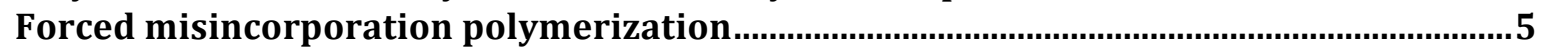

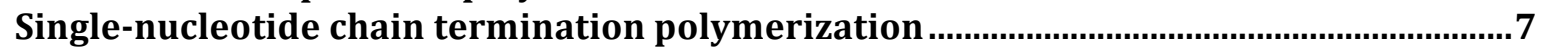

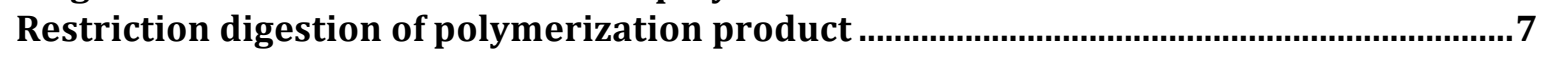

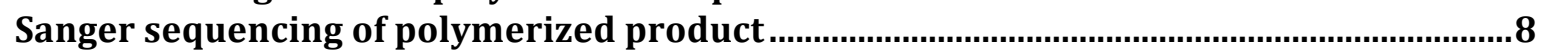

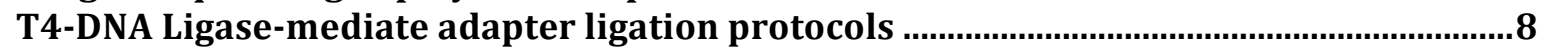

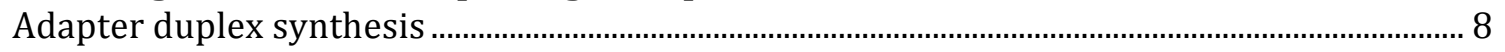

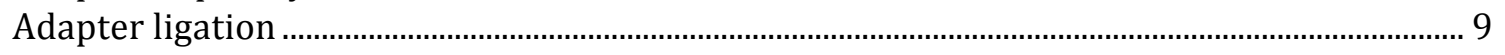

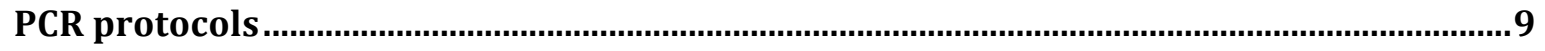

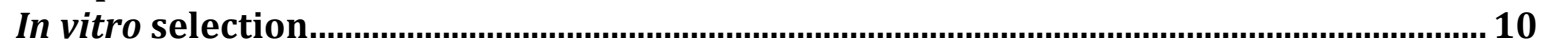

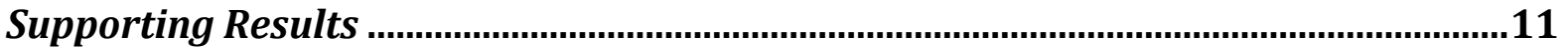

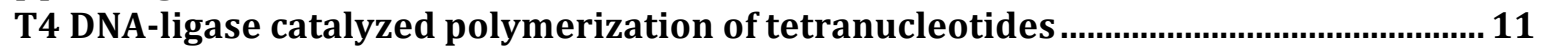

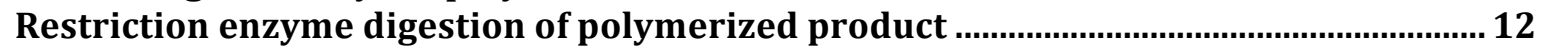

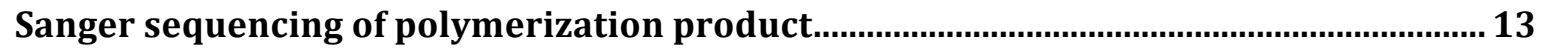

Influence of modification site on polymerization efficiency …..............................................

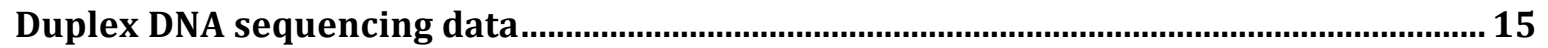

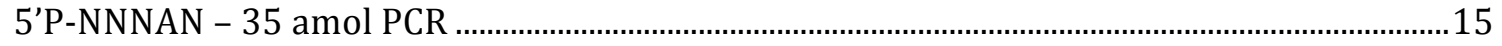

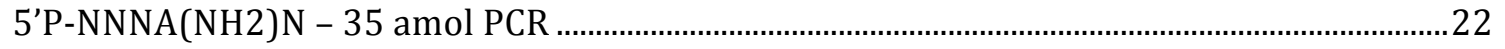

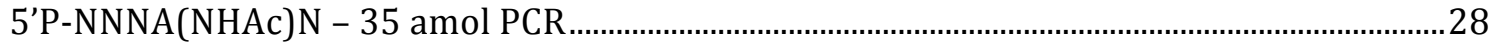

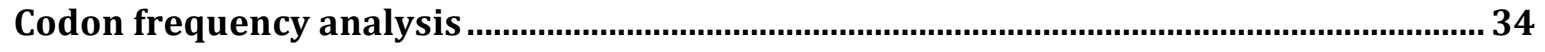




\section{Supporting Methods}

\section{General Information}

Unless otherwise noted, water was purified with Milli-Q purification system. DNA oligonucleotides without amine modification were purchased from Integrated DNA Technologies. DNA oligonucleotides with amine modification were synthesized on a Bioautomation Mermade 12 synthesizer. All materials and reagents used for oligonucleotide synthesis were purchased from Glen Research. All oligonucleotides were synthesized and deprotected according to the manufacturer's protocols. Oligonucleotides were purified by reverse-phase high-pressure liquid chromatography (HPLC, Agilent 1260) using a C18 stationary phase (Eclipse-XDB C18, $5 \mu \mathrm{m}, 9.4 \times 200 \mathrm{~mm}$ ) and an acetonitrile/100 mM triethylammonium acetate gradient. Oligonucleotide concentrations were quantitated by UV spectroscopy using a Nanodrop ND2000 spectrophotometer.

\section{DNA sequences}

The sequences below are written from $5^{\prime} \rightarrow 3^{\prime}$. $<$ Aam $>=$ Amino-modifer $\mathrm{C} 6 \mathrm{dA}$, $<\mathrm{N}>=\mathrm{A} / \mathrm{T} / \mathrm{C} / \mathrm{G},<\mathrm{W}>=\mathrm{A} / \mathrm{T}$

\section{Templates}

TP(NNNNN)8P /5Phos/GA TTC GCC TGC CGT CGC ANN NNN NNN NNN NNN NNN NNN NNN NNN NNN NNN NNN NNN NNC ACG TGG AGC TCG GAT CCT

TP(WNWNT)8P /5Phos/GA TTC GCC TGC CGT CGC AWN WNT WNW NTW NWN TWN WNT WNW NTW NWN TWN WNT WNW NTC ACG TGG AGC TCG GAT CCT

TP(NNNNT)8P /5Phos/GA TTC GCC TGC CGT CGC ANN NNT NNN NTN NNN TNN NNT NNN NTN NNN TNN NNT NNN NTC ACG TGG AGC TCG GAT CCT

TP(NNNTN)8P /5Phos/GA TTC GCC TGC CGT CGC ANN NTN NNN TNN NNT NNN NTN NNN TNN NNT NNN NTN NNN TNC ACG TGG AGC TCG GAT CCT

TP(NNTNN)8P /5Phos/GA TTC GCC TGC CGT CGC ANN TNN NNT NNN NTN NNN TNN NNT NNN NTN NNN TNN NNT NNC ACG TGG AGC TCG GAT CCT

TP(NTNNN)8P /5Phos/GA TTC GCC TGC CGT CGC ANT NNN NTN NNN TNN NNT NNN NTN NNN TNN NNT NNN NTN NNC ACG TGG AGC TCG GAT CCT

TP(TNNNN)8P /5Phos/GA TTC GCC TGC CGT CGC ATN NNN TNN NNT NNN NTN NNN TNN NNT NNN NTN NNN TNN NNC ACG TGG AGC TCG GAT CCT 


\section{Primers}

PR5 /5Phos/GG ATC CGA GCT CCA CGT G

PR6 /5Phos/TG CGA CGG CAG GCG AAT CT

iTruS_i7_D701 CAA GCA GAA GAC GGC ATA CGA GAT ATT ACT CGG TGA CTG GAG TTC AG iTruS_i7_D702 CAA GCA GAA GAC GGC ATA CGA GAT TCC GGA GAG TGA CTG GAG TTC AG iTruS_i7_D703 CAA GCA GAA GAC GGC ATA CGA GAT CGC TCA TTG TGA CTG GAG TTC AG iTruS_i7_D704 CAA GCA GAA GAC GGC ATA CGA GAT GAG ATT CCG TGA CTG GAG TTC AG iTruS_i7_D705 CAA GCA GAA GAC GGC ATA CGA GAT ATT CAG AAG TGA CTG GAG TTC AG iTruS_i7_D706 CAA GCA GAA GAC GGC ATA CGA GAT GAA TTC GTG TGA CTG GAG TTC AG iTruS_i7_D707 CAA GCA GAA GAC GGC ATA CGA GAT CTG AAG CTG TGA CTG GAG TTC AG iTruS_i7_D708 CAA GCA GAA GAC GGC ATA CGA GAT TAA TGC GCG TGA CTG GAG TTC AG iTruS_i7_D709 CAA GCA GAA GAC GGC ATA CGA GAT CGG CTA TGG TGA CTG GAG TTC AG iTruS_i7_D710 CAA GCA GAA GAC GGC ATA CGA GAT TCC GCG AAG TGA CTG GAG TTC AG iTruS_i7_D711 CAA GCA GAA GAC GGC ATA CGA GAT TCT CGC GCG TGA CTG GAG TTC AG iTruS_i7_D712 CAA GCA GAA GAC GGC ATA CGA GAT AGC GAT AGG TGA CTG GAG TTC AG PRIMER B AAT GAT ACG GCG ACC ACC GAG

Adapters

Adapter A AAT GAT ACG GCG ACC ACC GAG ATC TAC ACT CTT TCC CTA CAC GAC GCT CTT CCG ATC T

Adapter B /5phos/AC TGN NNN NNN NNN NNA GAT CGG AAG AGC ACA CGT CTG AAC TCC AGT CAC

Pentanucleotides

NNNNN /5Phos/NNNNN

ANWNW /5Phos/ANWNW

ANNNN /5Phos/ANNNN 
$\mathrm{NH}_{2}$-ANNNN/5Phos/<Ama $>$ NNNN

NANNN /5Phos/NANNN

$\mathbf{N H}_{2}$-NANNN $/ 5$ Phos $/ \mathrm{N}<$ Ama $>\mathrm{NNN}$

NNANN /5Phos/NNANN

$\mathbf{N H}_{2}$-NNANN $/ 5$ Phos/NN $<$ Ama $>$ NN

NNNAN /5Phos/NNNAN

$\mathrm{NH}_{2}$-NNNAN /5Phos/NNN $<$ Ama $>\mathrm{N}$

NNNNA /5Phos/NNNNA

$\mathbf{N H}_{\mathbf{2}}$-NNNNA /5Phos/NNNN $<$ Ama $>$

\section{Synthesis of amino-modified pentanucleotides}

Pentanucleotides were synthesized on a Mermaid 12 DNA synthesizer using a DMT-ON protocol on a $1 \mu \mathrm{mol}$ scale (1000 A CPG column). Amine-modifier C6 dA (Glen Research 101089), $d A+d C+d G+d T-C E$ Phosphoramindite (Glen Research 10-1000, 10-1010, 10-1020, 101030), Chemical Phosphorylation Reagent II (10-1901) were incorporated as specified by the manufacturer. Following synthesis, the oligonucleotide was cleaved from the resin by incubation at $65^{\circ} \mathrm{C}$ in $500 \mu \mathrm{L}$ of a $1: 1$ mixture of ammonium hydroxide and methylamine for 15 minutes. The cleaved resin was filtered away by filtration, and the oligonucleotide was concentrated under reduced pressure using a speedvac. The residue was then taken up into $100 \mu \mathrm{L}$ of $\mathrm{H} 2 \mathrm{O}$, and purified using reverse-phase HPLC purification using a [10\% acetonitrile in $0.1 \mathrm{M}$ TEAA, $\mathrm{pH}$ 7] to [80\% acetonitrile in $0.1 \mathrm{M}$ TEAA, $\mathrm{pH}$ 7] solvent gradient with a column temperature of $45^{\circ} \mathrm{C}$. The purified oligonucleotide was then incubated at room temperature in $500 \mu \mathrm{L}$ of $80 \%$ aqueous acetic acid for $1 \mathrm{~h}$ to cleave the DMT group, and then frozen and lyophilized. The oligonucleotide was incubated in $500 \mu \mathrm{L} 30 \%$ ammonium hydroxide at room temperature for 15 minutes to cleave the CPRII linker. Following deprotection, the oligonucleotide was concentrated under reduced pressure using a speedvac. The dried product was dissolved into $100 \mu \mathrm{L} \mathrm{H} 2 \mathrm{O}$ and subjected to reverse-phase HPLC purification using a [10\% acetonitrile in $0.1 \mathrm{M} \mathrm{TEAA}, \mathrm{pH}$ 7] to [ $80 \%$ acetonitrile in $0.1 \mathrm{M}$ TEAA, pH 7] solvent gradient with a column temperature of $45^{\circ} \mathrm{C}$. The purified oligonucleotide was dissolved in water. 


\section{T4-DNA Ligase-mediate polymerization protocols}

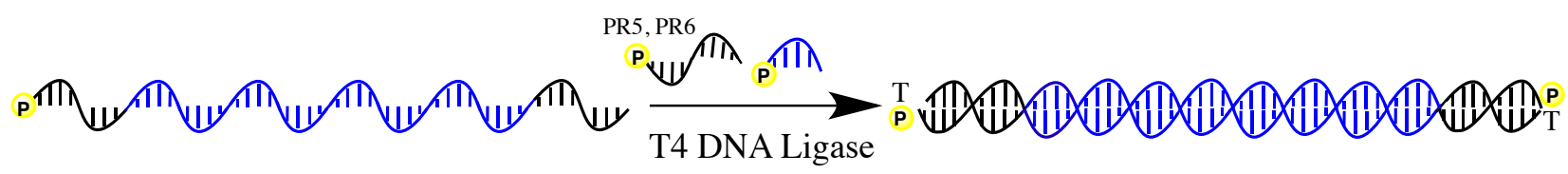

In a PCR tube was added DNA template (15 pmol in $1.5 \mu$ l water), PR5 (22.5 pmol in $2.25 \mu \mathrm{l}$ water), PR6 (22.5 pmol in $2.25 \mu$ l water), $4 \mu$ I NEBNext ${ }^{\circledR}$ Quick Ligation Reaction Buffer $5 \mathrm{X}, 7$ $\mu$ l water. The mix was heated to $90{ }^{\circ} \mathrm{C}$ for 2 minutes and then cooled to $25^{\circ} \mathrm{C}$ at the rate of $0.1^{\circ} \mathrm{C} / \mathrm{s}$. In this PCR tube was then added pentanuclotides (480 pmol in $1 \mu \mathrm{l}$ water), BSA ( $2 \mu \mathrm{g}$ in $1 \mu \mathrm{l}$ water) and $400 \mathrm{U}$ T4 DNA ligase (New England Biolabs, M0202L). The polymerization was performed at $25{ }^{\circ} \mathrm{C}$ for 24 hours. The products were then purified with MinElute ${ }^{\oplus}$ PCR Purification Kit for adapter ligation.

\section{Polymerization efficiency with fluorescently-labeled primers}

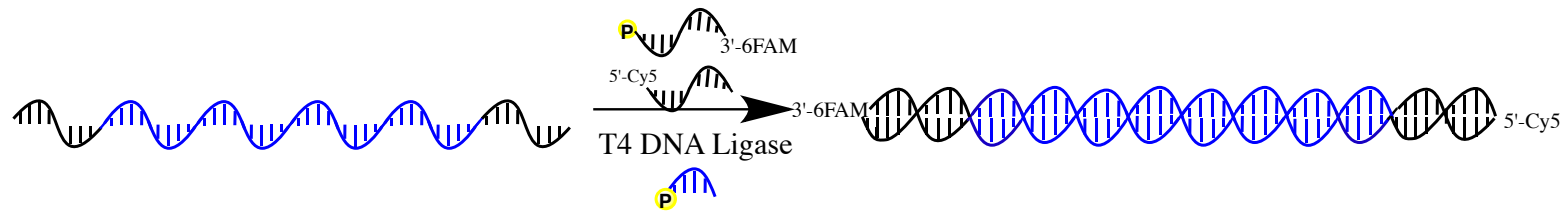

In a PCR tube was added DNA template TP(NNNNT)8P (15 pmol in $1.5 \mu \mathrm{l}$ water), 5' Cy5 modified PR5 (22.5 pmol in $2.25 \mu \mathrm{l}$ water), 3' 36FAM modified PR6 (22.5pmol in 2.25 $\mu \mathrm{l}$ water), $4 \mu \mathrm{l}$ NEBNext ${ }^{\oplus}$ Quick Ligation Reaction Buffer $5 \times, 7 \mu l$ water for the experimental reaction, and $8 \mu \mathrm{l}$ water for the two control reactions. The mix was heated to $90{ }^{\circ} \mathrm{C}$ for 2 minutes and then cooled to $25^{\circ} \mathrm{C}$ at the rate of $0.1{ }^{\circ} \mathrm{C} / \mathrm{s}$. In experimental reaction PCR tube was then added pentanucleotides ANNNN (480 pmol in $1 \mu \mathrm{l}$ water), BSA ( $2 \mu \mathrm{g}$ in $1 \mu \mathrm{l}$ water) and $400 \mathrm{U}$ T4 DNA ligase (New England Biolabs, M0202L). In one of the control reaction was added pentanucleotides ANNNN (480 pmol in $1 \mu$ l water) and BSA ( $2 \mu \mathrm{g}$ in $1 \mu \mathrm{l}$ water). The other control reaction was added 400 U T4 DNA ligase (New England Biolabs, M0202L) and BSA $\left(2 \mu \mathrm{g}\right.$ in $1 \mu \mathrm{l}$ water). The polymerization was performed at $25{ }^{\circ} \mathrm{C}$ for 24 hours. The products were then purified with MinElute ${ }^{\circledast}$ PCR Purification Kit. The gel was imaged using a Typhoon 9410 imager.

\section{Forced misincorporation polymerization}

DNA template

matched-3' TCTCTTCTCTTCTCTTCTCTTCTCTTCTCTTCTCTTCTCTACGCTGCCGTCCCCTTGGAC GGCAGCGTAGAGA

mismatch1-3' TCTCTTCTCTTCTCTTCTCTTCTCTTCTCTTCTCTTCTCTACGCTGCCGTCCCCTTGGAC GGCAGCGTAGACA

mismatch2-3' TCTCTTCTCTTCTCTTCTCTTCTCTTCTCTTCTCTTCTCTACGCTGCCGTCCCCTTGGAC GGCAGCGTAGTGA

mismatch3-3' TCTCTTCTCTTCTCTTCTCTTCTCTTCTCTTCTCTTCTCTACGCTGCCGTCCCCTTGGAC GGCAGCGTACAGA 
mismatch4-3' TCTCTTCTCTTCTCTTCTCTTCTCTTCTCTTCTCTTCTCTACGCTGCCGTCCCCTTGGAC GGCAGCGTTGAGA

matched-5' /5Phos/AGAGATGCGACGGCAGGTTCCCCTGCCGTCGCATCTCTTCTCTTCTCTTCTCT TCTCTTCTCTTCTCTTCTCTC

mismatch1-5' /5Phos/ACAGATGCGACGGCAGGTTCCCCTGCCGTCGCATCTCTTCTCTTCTCTTCTC TTCTCTTCTCTTCTCTTCTCTC

mismatch2-5' /5Phos/ACTGATGCGACGGCAGGTTCCCCTGCCGTCGCATCTCTTCTCTTCTCTTCTC TTCTCTTCTCTTCTCTTCTCTC

mismatch3-5' /5Phos/ACAGATGCGACGGCAGGTTCCCCTGCCGTCGCATCTCTTCTCTTCTCTTCTC TTCTCTTCTCTTCTCTTCTCTC

mismatch4-5' /5Phos/ACAGTTGCGACGGCAGGTTCCCCTGCCGTCGCATCTCTTCTCTTCTCTTCTC TTСТСТTСТСТTСТСТTСТСТC

matchedB-3' TCTCTTCTCTTCTCTTCTCTTCTCTTCTCTTCTCTTCTCTACGCTGCCGTCCCCTTGGAC GGCAGCGT

mismatchedB1-3' TCTCTTCTCTTCTCTTCTCTTCTCTTCTCTTCTCTTCTCAACGCTGCCGTCCCCTTG GACGGCAGCGT

mismatchedB2-3' TCTCTTCTCTTCTCTTCTCTTCTCTTCTCTTCTCTTCTGTACGCTGCCGTCCCCTTG GACGGCAGCGT

mismatchedB3-3' TCTCTTCTCTTCTCTTCTCTTCTCTTCTCTTCTCTTCACTACGCTGCCGTCCCCTTG GACGGCAGCGT

mismatchedB4-3' TCTCTTCTCTTCTCTTCTCTTCTCTTCTCTTCTCTTGTCTACGCTGCCGTCCCCTTG GACGGCAGCGT

mismatchedB5-3' TCTCTTCTCTTCTCTTCTCTTCTCTTCTCTTCTCATCTCTACGCTGCCGTCCCCTTG GACGGCAGCGT

matchedB-5' /5Phos/TGCGACGGCAGGTTCCCCTGCCGTCGCATCTCTTCTCTTCTCTTCTCTTCTCT TCTCTTCTCTTCTCTC

mismatchedB1-5' /5Phos/TGCGACGGCAGGTTCCCCTGCCGTCGCAACTCTTCTCTTCTCTTCTC TTCTCTTCTCTTCTCTTCTCTC

mismatchedB2-5' /5Phos/TGCGACGGCAGGTTCCCCTGCCGTCGCATGTCTTCTCTTCTCTTCTC TTCTCTTCTCTTCTCTTCTCTC

mismatchedB3-5' /5Phos/TGCGACGGCAGGTTCCCCTGCCGTCGCATCACTTCTCTTCTCTTCTC TTCTCTTCTCTTCTCTTCTCTC

mismatchedB4-5' /5Phos/TGCGACGGCAGGTTCCCCTGCCGTCGCATCTGTTCTCTTCTCTTCTC TTCTCTTCTCTTCTCTTCTCTC

mismatchedB5-5' /5Phos/TGCGACGGCAGGTTCCCCTGCCGTCGCATTCATCTCTTCTCTTCTC TTCTCTTCTCTTCTCTTCTCTC

Pentanucleotides

P-AGAGA 5Phos/AGAGA

Protocol

In the PCR tube was added DNA template (15 pmol in $1.5 \mu$ l water), $4 \mu$ l NEBNext Quick Ligation Reaction Buffer $5 \mathrm{X}, 11.5 \mu \mathrm{l}$ water. The mix was heated to $90{ }^{\circ} \mathrm{C}$ for 2 minutes and then cooled to $25^{\circ} \mathrm{C}$ at the rate of $0.1{ }^{\circ} \mathrm{C} / \mathrm{s}$. In all tubes were added BSA ( $2 \mu \mathrm{g}$ in $1 \mu$ l water), 400 U T4 DNA ligase (New England Biolabs, M0202L) and P-AGAGA (480 pmol in $1 \mu$ l water). 
The products were then purified with MinElute ${ }^{\oplus}$ PCR Purification Kit. PAGE analysis was then performed (15\% Mini-PROTEAN ${ }^{\circledR}$ TBE-Urea Gel) at $55^{\circ} \mathrm{C}$ for 90 minutes.

\title{
Single-nucleotide chain termination polymerization
}

\author{
DNA template \\ idelitymixA1-c-5' 5Phos/TG CGA CGG CAG GTT CCC CTG CCG TCG CAT CTC TAG AGT AGA \\ GTA GAG TAG AGT AGA GTA GAG TAG AGT C
}

\author{
Pentanucleotides \\ P-ACTCT 5Phos/ACTCT \\ P-AGAGA 5Phos/AGAGA \\ TGAGA TGAGA \\ ACAGA ACAGA \\ AGTGA AGTGA \\ AGAGT AGAGT
}

\section{Protocol}

In 5 PCR tubes were added DNA template (15 pmol in $1.5 \mu$ l water), $4 \mu$ l NEBNext Quick Ligation Reaction Buffer $5 \mathrm{X}, 11.5 \mu \mathrm{l}$ water. The mix was heated to $90{ }^{\circ} \mathrm{C}$ for 2 minutes and then cooled to $25^{\circ} \mathrm{C}$ at the rate of $0.1{ }^{\circ} \mathrm{C} / \mathrm{s}$. In all tubes were added BSA ( $2 \mu \mathrm{g}$ in $1 \mu$ l water), $400 \mathrm{U}$ T4 DNA ligase (New England Biolabs, M0202L) and P-ACTCT (420 pmol in $1 \mu \mathrm{l}$ water). In the first tube was added P-AGAGA (60 pmol in $1 \mu$ l water), the second tube was added TGAGA $(60 \mathrm{pmol}$ in $1 \mu \mathrm{l}$ water), the third tube was added TGAGA/ACAGA/AGTGA/AGACA/AGAGT mixture $(60 \mathrm{pmol}$ each, $300 \mathrm{pmol}$ total in $5 \mu \mathrm{l}$ water), the fourth tube was added mixture (120 pmol each, 600 pmol total in $5 \mu \mathrm{l}$ water), and the fifth tube was added mixture (180 pmol each, $900 \mathrm{pmol}$ total in $5 \mu \mathrm{l}$ water). The polymerization was performed at $25{ }^{\circ} \mathrm{C}$ for 24 hours. The products were then purified with MinElute ${ }^{\circledast}$ PCR Purification Kit. PAGE analysis was then performed (15\% Mini-PROTEAN ${ }^{\circledR}$ TBE-Urea Gel) at $55^{\circ} \mathrm{C}$ for 90 minutes.

\section{Restriction digestion of polymerization product}

\section{DNA template}

TP(rand1)8P GAT TCG CCT GCC GTC GCA TCT CTT CTC TTC TCT TCT CTT CTC TTC TCT TCT CTT CTC TCA CGT GGA GCT CGG ATC C

\section{Protocol}

In a PCR tube polymerization was performed with TP(rand1)8P and ANNNN following the T4-DNA ligase-mediate polymerization protocol.

In another PCR tube was added DNA template TP(rand1)8P (15 pmol in $1.5 \mu$ l water), PR1 (22.5 pmol in $2.25 \mu \mathrm{l}$ water), $5 \mu \mathrm{l}$ 10x NEBuffer2 (New England Biolabs, M0212L), $37.5 \mu \mathrm{l}$ water. The mix was heated to $90{ }^{\circ} \mathrm{C}$ for 2 minutes and then cooled to $37^{\circ} \mathrm{C}$ at the rate of 0.1 ${ }^{\circ} \mathrm{C} / \mathrm{s}$. The tube was then added $5 \cup$ Klenow Fragment $\left(3^{\prime} \rightarrow 5^{\prime}\right.$ exo', New England Biolabs, M0212L) and dNTP (1.25 $\mu 10 \mathrm{mM}$ stock solution, Thermo Scientific, R0192). The extension 
was then performed at $37^{\circ} \mathrm{C}$ for 1 hour. The products were then purified with MinElute PCR Purification Kit for further digestion.

In the PCR tubes were added $10 \mu \mathrm{l}$ polymerized dsDNA and extended dsDNA separately, $5 \mu \mathrm{l}$ 10x CutSmart $^{\circledast}$ Buffer (New England Biolabs, R0542S), 10 U BcoDI (New England Biolabs, $\mathrm{R} 0542 \mathrm{~S}$ ) and $34 \mu \mathrm{l}$ water. The mix was then incubated at $37^{\circ} \mathrm{C}$ overnight. The digestion products were purified with Centri-Sep columns (Princeton Separations, CS-900). PAGE analysis was then performed (15\% Mini-PROTEAN ${ }^{\circledR}$ TBE-Urea Gel) at $55^{\circ} \mathrm{C}$ for 90 minutes.

\section{Sanger sequencing of polymerized product}

\section{DNA template}

\section{TP(rand1)8PS GAT TCG CCT GCC GTC GCA TCT CTT CTC TTC TCT TCT CTT CTC TTC TCT TCT} CTT CTC TCA CGT GGA GCT CGG ATC C/iSp18/A ACA ACA ACA ACA A

\section{Protocol}

In a PCR tube polymerization was performed with TP(rand1)8PS and ANNNN following the T4-DNA ligase-mediate polymerization protocol.

In another PCR tube was added DNA template TP(rand1)8PS (15 pmol in $1.5 \mu$ l water), PR1 (22.5 pmol in $2.25 \mu \mathrm{l}$ water), $5 \mu \mathrm{l}$ 10x NEBuffer2 (New England Biolabs, M0212L), $37.5 \mu \mathrm{l}$ water. The mix was heated to $90^{\circ} \mathrm{C}$ for 2 minutes and then cooled to $37^{\circ} \mathrm{C}$ at the rate of 0.1 ${ }^{\circ} \mathrm{C} / \mathrm{s}$. The tube was then added $5 \cup$ Klenow Fragment $\left(3^{\prime} \rightarrow 5^{\prime}\right.$ exo', New England Biolabs, M0212L) and dNTP (1.25 $\mu 10 \mathrm{mM}$ stock solution, Thermo Scientific, R0192). The extension was then performed at $37^{\circ} \mathrm{C}$ for 1 hour. The products were then purified with MinElute PCR Purification Kit.

The polymerized strand and extended strand were then purified by gel purification ( $15 \%$ Mini-PROTEAN ${ }^{\circledR}$ TBE-Urea Gel). After stained with $0.5 \times$ SYBR $^{\circledR}$ safe DNA gel stain (Life Technologies, S33100) for 30 minutes, the product bands were cut out and the nucleotides were eluted with $0.3 \mathrm{M} \mathrm{NaCl}$ at room temperature over night. The products were then purified with Centri-Sep columns (Princeton Separations, CS-900). The nucleotides were then amplified with 16-cycle and 25-cycle PCR for extended strand and polymerized strand separately. The PCR products were sent to Georgia Genomic Facility at UGA for SANGER sequencing.

\section{T4-DNA Ligase-mediate adapter ligation protocols}

\section{Adapter duplex synthesis}

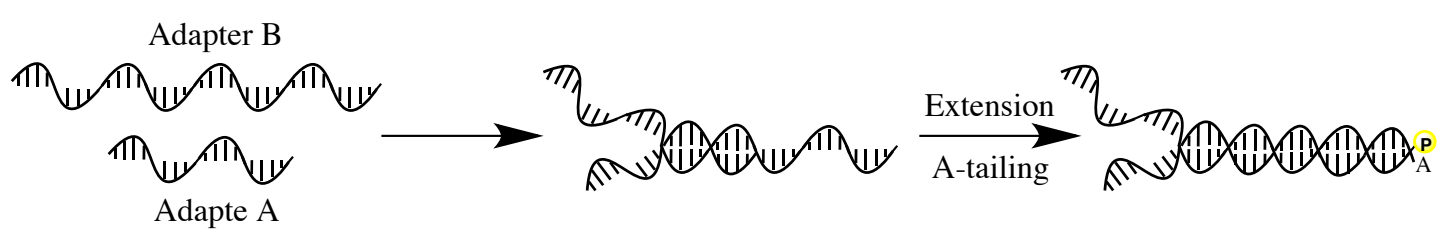

In a PCR tube was added $15 \mu \mathrm{l}$ of $100 \mu \mathrm{M}$ adapter $\mathrm{A}$ and $15 \mu \mathrm{l}$ of $100 \mu \mathrm{M}$ adapter $\mathrm{B}$, then the tube was heated to $95{ }^{\circ} \mathrm{C}$ for 5 minutes, and cooled to room temperature over 1 hour. Then in this PCR tube was added $4 \mu \mathrm{l}$ NEBuffer 2 10x (New England Biolabs, M0212L), $25 \mathrm{U}$ Klenow Fragment $\left(3^{\prime} \rightarrow 5^{\prime}\right.$ exo', New England Biolabs, M0212L), $1 \mu$ dNTP Mix (Thermo 
Scientific, $10 \mathrm{mM}$ each). The extension was performed at $37{ }^{\circ} \mathrm{C}$ for 1 hour. The adapter duplex was purified with QIAquick Nucleotide Removal Kit, and then diluted in $30 \mu \mathrm{l}$ water.

In a PCR tube was added 30 $\mu$ l purified adapter duplex, $5 \mu$ l NEBuffer 2 10x (New England Biolabs, M0212L), 25 U Klenow Fragment $\left(3^{\prime} \rightarrow 5^{\prime}\right.$ exo', New England Biolabs, M0212L), $5 \mu \mathrm{l}$ dATP (Thermo Scientific, $10 \mathrm{mM}$ ), $5 \mu$ l water. This PCR tube was incubated at $37^{\circ} \mathrm{C}$ for 1 hour for A-tailing. Then product was purified with QIAquick Nucleotide Removal Kit, and then diluted in $30 \mu$ l water.

\section{Adapter ligation}

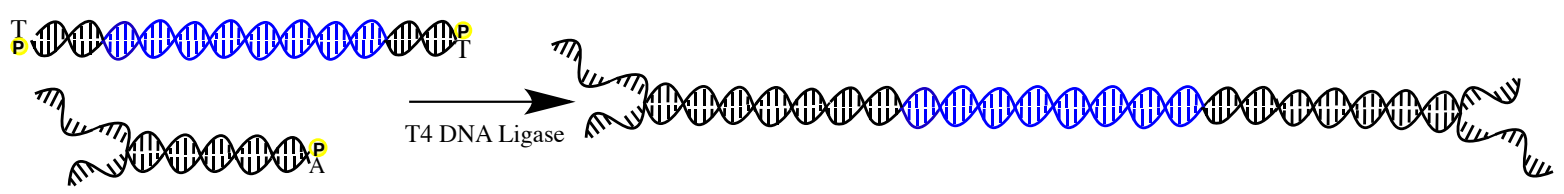

In a PCR tube was added polymerization products (12 pmol in $10 \mu \mathrm{l}$ water), A-tailing adapter duplex (240 pmol), 10 $\mu \mathrm{l}$ NEBNext ${ }^{\circledR}$ Quick Ligation Reaction Buffer $5 \mathrm{x}$, BSA (5 $\mu \mathrm{g}$ in $2.5 \mu \mathrm{l}$ water), 1000 U T4 DNA ligase (New England Biolabs, M0202L), water (make total volume 50 $\mu \mathrm{l})$. Then the ligation was performed at $16{ }^{\circ} \mathrm{C}$ for 16 hours, resulting in approximately $40 \%$ conversion into desired double-ligated product. Gel purification was then performed. The products were diluted to $10 \mu$ l water.

\section{PCR protocols}

Each purified adapter ligation product was amplified with a different primer from iTrus_D701 to iTrus_D712. The combinations were shown below:

iTrus_D701+ TP(NNNNN)8P+ NNNNN

iTrus_D702+TP(WNWNT)8P+ ANWNW

iTrus_D703+ TP(NNNNT)8P+ ANNNN

iTrus_D704+ TP(NNNNT)8P+ $\mathrm{NH}_{2}-\mathrm{ANNNN}$

iTrus_D705+ TP(NNNTN)8P+ NANNN

iTrus_D706+ TP(NNNTN)8P+ $\mathrm{NH}_{2}-\mathrm{NANNN}$

iTrus_D707+ TP(NNTNN)8P+ NNANN

iTrus_D708+ TP(NNTNN) $8 \mathrm{P}+\mathrm{NH}_{2}-\mathrm{NNANN}$

iTrus_D709+ TP(NTNNN)8P+ NNNAN

iTrus_D710+ TP(NTNNN)8P+ $\mathrm{NH}_{2}-\mathrm{NNNAN}$

iTrus_D711+ TP(TNNNN)8P+ NNNNA

iTrus_D712+ TP(TNNNN)8P+ $\mathrm{NH}_{2}-\mathrm{NNNNA}$

In a PCR tube was added $1 \mu \mathrm{l}$ purified adapter ligation product, $1.25 \mu \mathrm{l} 10 \mu \mathrm{M}$ Primer $\mathrm{B}, 1.25$ $\mu \mathrm{l} 10 \mu \mathrm{M}$ corresponding iTrus_D7XX primer, $9 \mu \mathrm{l}$ water and $12.5 \mu \mathrm{l}$ Q $5^{\circ}$ High-Fidelity $2 \times$ Master Mix (New England Biolabs). The tube was then transferred to a preheated themocylcler $\left(98^{\circ} \mathrm{C}\right)$. The annealing temperature was $55^{\circ} \mathrm{C}$ for the first two cycles, and remained $71{ }^{\circ} \mathrm{C}$ for the rest of the cycles.

The PCR cycles were 20 for iTrus_D704 and iTrus_D712 since the corresponding adapter ligation yields were lower, and all the others were amplified for 10 cycles. The PCR products were then purified by gel purification. 


\section{In vitro selection}

\section{DNA template}

POS2(rand1) /5BiosG/GA TTC GCC TGC CGT CGC AGC TCT TCC GTC ACG TAC CTT AGT TTG CCA TCG TCT CAC CTC ACG TGG AGC TCG GAT

\section{Protocol}

Polymerization was performed with the template mixture of POS2(rand1) :TP(NTNNN)8P= $1: 100$, following the following the T4-DNA ligase-mediate polymerization protocol with NNNAN pentanucleotides. The polymerized products were then incubated with $30 \mu \mathrm{l}$ streptavidin magnetic beads (Life Technologies, Dynabeads ${ }^{\circledR}$ MyOne $^{\mathrm{TM}}$ Streptavidin C1), which were washed with $200 \mu$ l binding buffer $(0.5 \mathrm{M} \mathrm{NaCl}, 200 \mathrm{mM}$ Tris- $\mathrm{HCl}$ pH=7.5, $1 \mathrm{mM}$ EDTA) 3 times before binding. After 30 minutes incubation at room temperature, TP(NTNNN)8P products were washed away with $200 \mu \mathrm{l}$ binding buffer 3 times. The dsDNA was then separated with $40 \mu$ freshly made $150 \mathrm{mM} \mathrm{NaOH}$. After incubation at room temperature for 15 minutes, $4 \mu \mathrm{l} 1.5 \mathrm{M} \mathrm{HCl}$ quenched the reaction. The liberated strand was then purified with Centri-Sep columns (Princeton Separations, CS-900). The products were then PCR amplified with 10 cycles. The products were then purified with MinElute ${ }^{\circledR}$ PCR Purification Kit for further digestion. In the PCR tubes were added $10 \mu \mathrm{ICR}$ amplified dsDNA, $5 \mu$ l 10x CutSmart $^{\circledast}$ Buffer (New England Biolabs, R0542S), 10 U BcoDI (New England Biolabs, R0542S) and $34 \mu \mathrm{l}$ water. The mix was then incubated at $37^{\circ} \mathrm{C}$ overnight. The digestion products were purified with Centri-Sep columns (Princeton Separations, CS-900). PAGE analysis was then performed (15\% Mini-PROTEAN ${ }^{\circledR}$ TBE-Urea Gel) at $55^{\circ} \mathrm{C}$ for 90 minutes. 


\section{Supporting Results}

\section{T4 DNA-ligase catalyzed polymerization of tetranucleotides}

The efficiency of polymerization decreased dramatically upon moving from a 64-codon unmodified tetranucleotide system to a 64-codon modified tetranucleotide system (Fig. S1). Upon evaluation of pentanucleotide codon systems, it was clear that larger sequence space and a greater number of modifications could be accommodated using a pentanucleotide codon set.

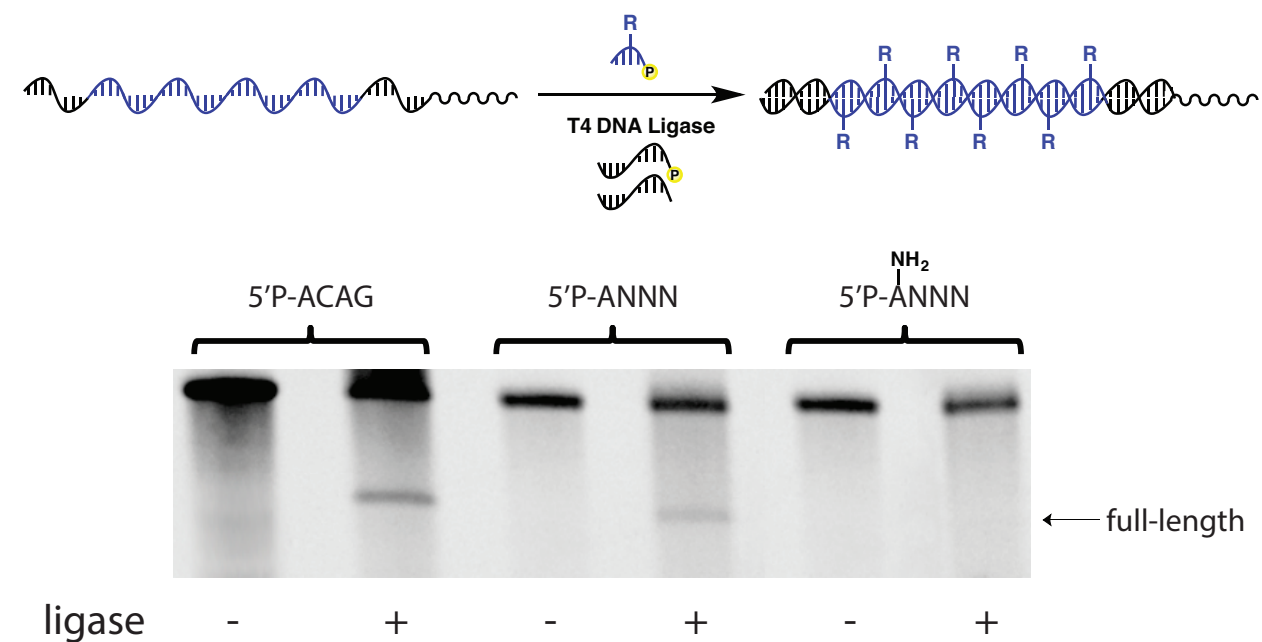

Fig. S1. Evaluation of tetramer libraries as substrates in the T4-DNA ligase-catalyzed polymerization of oligonucleotides. 


\section{Restriction enzyme digestion of polymerized product}

After identifying that T4 DNA ligase was able to efficiently polymerize large libraries of pentanucleotides along a corresponding DNA template, we undertook preliminary studies to assess the fidelity of the process. We designed a DNA template that contained a BcoDI digest site, which would allow us to evaluate the fidelity of polymerization around the digestion site (Fig. S2). T4 DNA ligase was challenged to correctly incorporate the correct pentanucleotides from the 5'P-ANNNN library along the DNA template. As a positive control, Klenow fragment was used to generate the correct DNA duplex prior to restriction digest. We found that the product of the T4 DNA ligase-catalyzed polymerization reaction was efficiently cleaved by Bcol, suggesting that highly specific incorporation of pentanucleotides was occurring at the digest site.
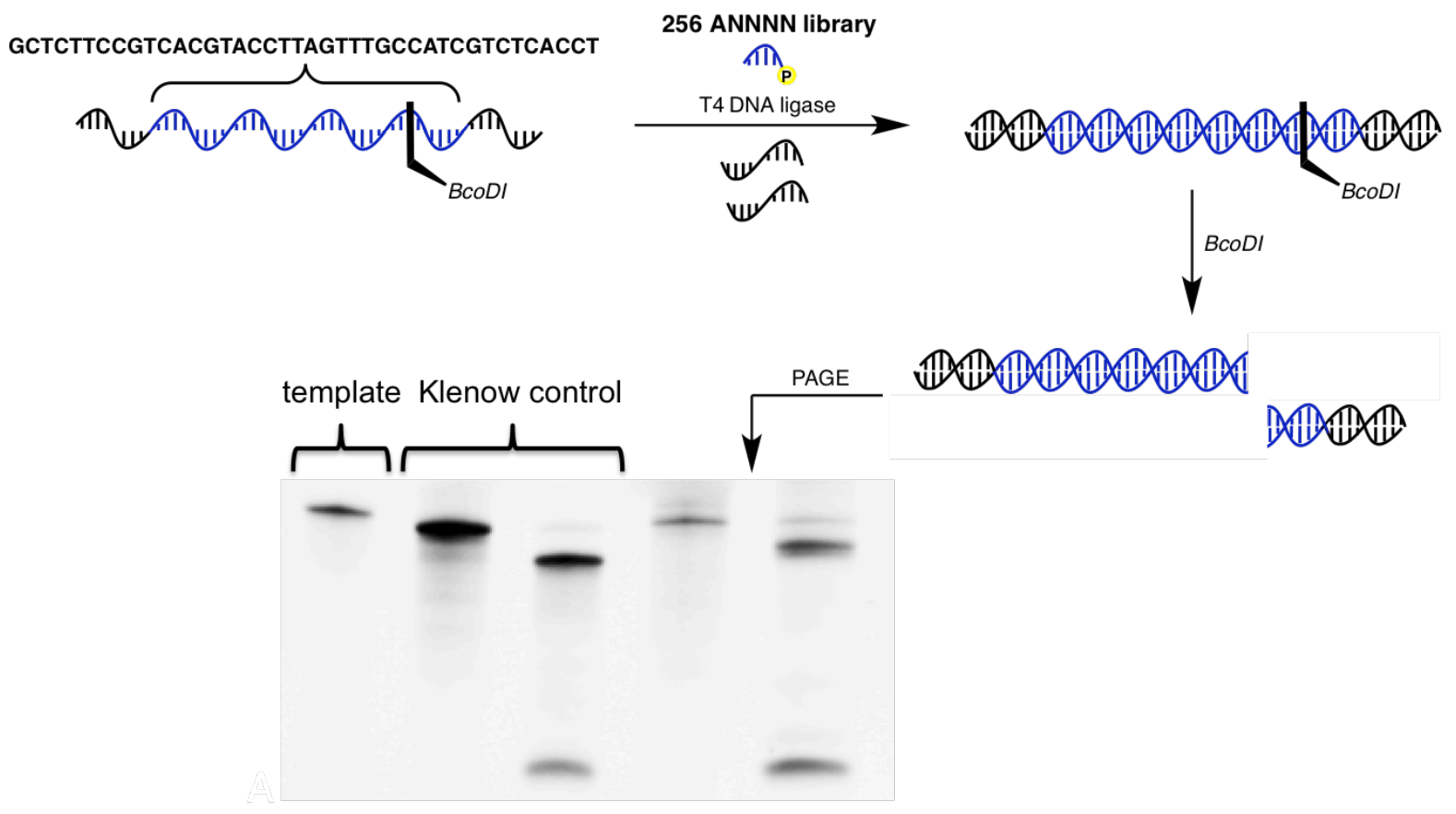

Fig. S2. Evaluation of sequence specificity by restriction enzyme digestion of synthesized duplex product. 


\section{Sanger sequencing of polymerization product}

The high fidelity of T4 DNA ligase was further supported by Sanger sequencing of the polymerized strand following PAGE purification, which revealed a consensus sequence that was the reverse complement of the starting template strand (Figure S3). These findings suggest that the polymerization proceeds with high fidelity.
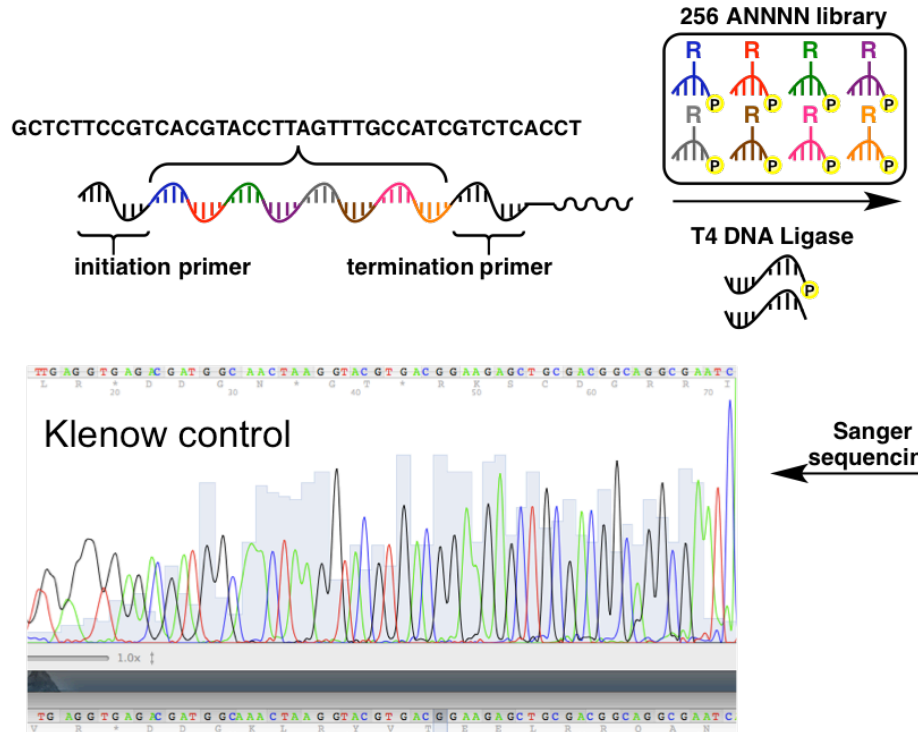

Ligase product

\section{Sanger} sequencing

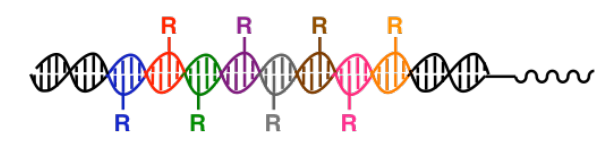
PAGE

PAGE $\downarrow$

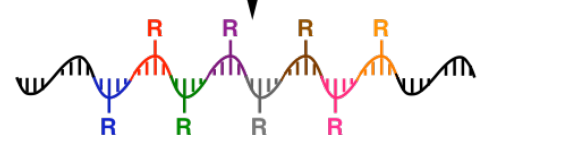

Figure S3. Sanger sequencing workflow for analyzing fidelity of polymerization. 


\section{Influence of modification site on polymerization efficiency}

Using a $3^{\prime}$-hairpin with $5^{\prime}$ primer binding site, the influence of nucleobase modification position on the polymerization efficiency was examined. For this experiment, the modification was the hexylamine on the $\mathrm{dA}$ nucleobase. The result in Figure S4 show that polymerization efficiency decreases sharply as the modification position moves from the $5^{\prime}$ end to the 3 '-end.

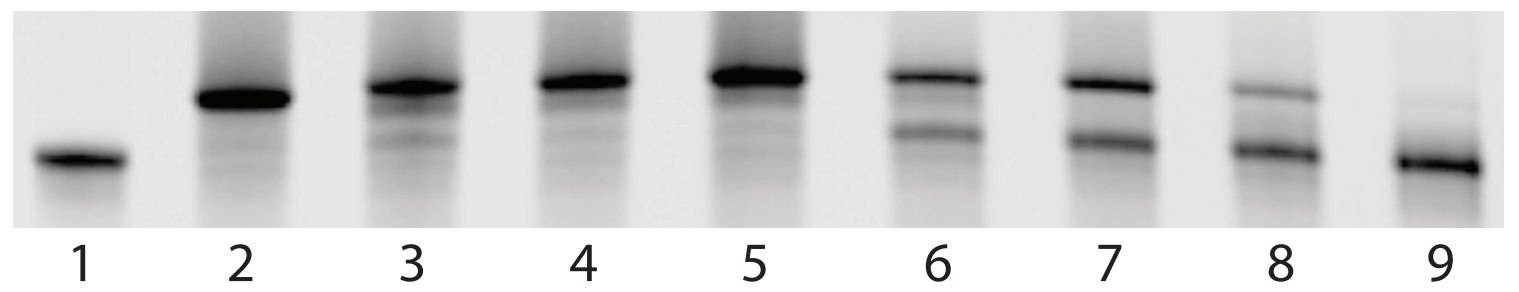

Figure S4. Influence of modification position. Lane 1: template; Lane 2: four equivalents/codon ANNNN unmodified control; Lane 3: four equivalents/codon $\mathrm{A}\left(\mathrm{NH}_{2}\right) \mathrm{NNNN}$; Lane 4: eight equivalents/codon $\mathrm{A}\left(\mathrm{NH}_{2}\right) \mathrm{NNNN}$; Lane 5: ten equivalents/codon $\mathrm{A}\left(\mathrm{NH}_{2}\right) \mathrm{NNNN}$; Lane 6: four equivalents/codon $\mathrm{NA}\left(\mathrm{NH}_{2}\right) \mathrm{NNN}$; Lane 7: four equivalents/codon $\mathrm{NNA}\left(\mathrm{NH}_{2}\right) \mathrm{NN}$; Lane 8: four equivalents/codon $\mathrm{NNNA}\left(\mathrm{NH}_{2}\right) \mathrm{N}$; Lane 9: four equivalents/codon $\mathrm{NNNNA}\left(\mathrm{NH}_{2}\right)$ 


\section{Duplex DNA sequencing data}

Note: Data is shown for 35 amol sequencing experiments of unmodified, aminohexylamine modified, and $N$-hexylacetamide modified pentanucleotides from the codon set NTNNN. Due to limited space, codon identities of misincorporation sites have been removed. All fastq files and processed sequencing data (.xls format) for all sequencing experiments are available upon request. Red colour indicates low fidelity pentanucleotides, while blue colour indicates high fidelity.

5'P-NNNAN - 35 amol PCR

\begin{tabular}{|c|c|c|c|c|}
\hline pentamer & codon & observed & errors & error rate \\
\hline CGGAA & TTCCG & 6618 & 621 & 9.383499547 \\
\hline ССТАТ & ATAGG & 7342 & 1345 & 18.31925906 \\
\hline CCTAA & TTAGG & 10321 & 1507 & 14.60129832 \\
\hline CCTAC & GTAGG & 9743 & 1508 & 15.47777892 \\
\hline CCTAG & CTAGG & 7082 & 712 & 10.05365716 \\
\hline CGCAC & GTGCG & 8996 & 1732 & 19.25300133 \\
\hline GATAG & CTATC & 5734 & 489 & 8.52807813 \\
\hline CGCAA & TTGCG & 8891 & 1454 & 16.35361602 \\
\hline CGCAG & CTGCG & 6166 & 934 & 15.14758352 \\
\hline GATAC & GTATC & 7445 & 792 & 10.63801209 \\
\hline GATAA & TTATC & 9592 & 1223 & 12.75020851 \\
\hline GATAT & ATATC & 6819 & 1075 & 15.76477489 \\
\hline CGCAT & ATGCG & 6805 & 1454 & 21.36664217 \\
\hline AGCAA & TTGCT & 9291 & 2445 & 26.31578947 \\
\hline TTCAT & ATGAA & 5734 & 1188 & 20.7185211 \\
\hline AGCAC & GTGCT & 8316 & 2129 & 25.6012506 \\
\hline CCAAT & ATTGG & 9320 & 2189 & 23.48712446 \\
\hline AGCAG & CTGCT & 6164 & 1386 & 22.48539909 \\
\hline CCAAA & TTTGG & 12906 & 2669 & 20.68030373 \\
\hline CCAAC & GTTGG & 12171 & 2589 & 21.27187577 \\
\hline TTCAA & TTGAA & 8289 & 1082 & 13.05344432 \\
\hline AGCAT & ATGCT & 6604 & 2118 & 32.07147184 \\
\hline CCAAG & CTTGG & 8709 & 1409 & 16.17866575 \\
\hline GAAAG & CTTTC & 7909 & 745 & 9.419648502 \\
\hline GAAAC & GTTTC & 10028 & 1142 & 11.38811328 \\
\hline GAAAA & TTTTC & 12768 & 1674 & 13.11090226 \\
\hline AACAG & CTGTT & 9140 & 1180 & 12.91028446 \\
\hline TATAT & ATATA & 7958 & 1806 & 22.69414426 \\
\hline AACAC & GTGTT & 12300 & 2196 & 17.85365854 \\
\hline AACAA & TTGTT & 15059 & 2645 & 17.56424729 \\
\hline GAAAT & ATTTC & 9255 & 1281 & 13.84116694 \\
\hline
\end{tabular}




\begin{tabular}{|c|c|c|c|c|}
\hline TATAG & CTATA & 6658 & 685 & 10.28837489 \\
\hline AACAT & ATGTT & 10965 & 2358 & 21.50478796 \\
\hline TATAA & TTATA & 10975 & 1561 & 14.22323462 \\
\hline TATAC & GTATA & 8656 & 1290 & 14.90295749 \\
\hline ACTAT & ATAGT & 8443 & 1643 & 19.45990762 \\
\hline ACTAC & GTAGT & 9372 & 1447 & 15.43960734 \\
\hline ACTAA & TTAGT & 11463 & 1855 & 16.18250022 \\
\hline ACTAG & CTAGT & 7186 & 992 & 13.80462009 \\
\hline CACAG & CTGTG & 8675 & 1273 & 14.67435159 \\
\hline CACAA & TTGTG & 13043 & 2727 & 20.90776662 \\
\hline CACAC & GTGTG & 12175 & 2328 & 19.1211499 \\
\hline ATGAT & ATCAT & 6960 & 1357 & 19.49712644 \\
\hline ATGAA & TTCAT & 10040 & 1646 & 16.39442231 \\
\hline ATGAC & GTCAT & 7963 & 1187 & 14.9064423 \\
\hline ATGAG & CTCAT & 6185 & 680 & 10.99434115 \\
\hline CGTAT & ATACG & 5707 & 951 & 16.66374628 \\
\hline CGTAG & CTACG & 5015 & 629 & 12.54237288 \\
\hline CGTAA & TTACG & 7854 & 930 & 11.84110008 \\
\hline CGTAC & GTACG & 7047 & 921 & 13.06939123 \\
\hline GTAAT & ATTAC & 7079 & 1362 & 19.24000565 \\
\hline GTAAG & CTTAC & 6127 & 771 & 12.58364616 \\
\hline GTAAA & TTTAC & 10019 & 1711 & 17.07755265 \\
\hline GTAAC & GTTAC & 7845 & 1245 & 15.86998088 \\
\hline AGGAG & СТССТ & 4829 & 736 & 15.24125078 \\
\hline AGGAA & ТTCCT & 7208 & 1381 & 19.15926748 \\
\hline AGGAC & GTCCT & 6298 & 1195 & 18.97427755 \\
\hline TCTAC & GTAGA & 6563 & 1126 & 17.15678805 \\
\hline TCTAA & TTAGA & 7835 & 1055 & 13.46522017 \\
\hline TCTAG & CTAGA & 5027 & 487 & 9.687686493 \\
\hline AGGAT & АТCCT & 5341 & 1301 & 24.35873432 \\
\hline TCCAG & CTGGA & 5766 & 999 & 17.32570239 \\
\hline CTCAG & CTGAG & 6046 & 638 & 10.55243136 \\
\hline ACAAC & GTTGT & 12414 & 2137 & 17.21443531 \\
\hline ACAAA & TTTGT & 15684 & 2882 & 18.37541444 \\
\hline ACAAG & CTTGT & 9767 & 1524 & 15.60356302 \\
\hline GTTAA & TTAAC & 7753 & 955 & 12.31781246 \\
\hline GTTAC & GTAAC & 6202 & 665 & 10.72234763 \\
\hline GTTAG & CTAAC & 4708 & 258 & 5.480033985 \\
\hline ACAAT & ATTGT & 11011 & 2217 & 20.13441104 \\
\hline GTTAT & ATAAC & 5478 & 832 & 15.18802483 \\
\hline TTCAG & CTGAA & 5180 & 491 & 9.478764479 \\
\hline TTCAC & GTGAA & 7023 & 1104 & 15.71977787 \\
\hline
\end{tabular}




\begin{tabular}{|c|c|c|c|c|}
\hline AAGAC & GTCTT & 9608 & 1250 & 13.00999167 \\
\hline CGAAG & CTTCG & 6460 & 1190 & 18.42105263 \\
\hline AAGAG & СТСТT & 7363 & 762 & 10.34904251 \\
\hline CGAAC & GTTCG & 8668 & 1609 & 18.56252884 \\
\hline CGAAT & ATTCG & 6957 & 1485 & 21.3454075 \\
\hline AAGAT & ATCTT & 8498 & 1442 & 16.96869852 \\
\hline TCTAT & ATAGA & 5558 & 1198 & 21.55451601 \\
\hline TACAT & ATGTA & 8084 & 2231 & 27.5977239 \\
\hline TGTAG & CTACA & 4504 & 640 & 14.20959147 \\
\hline TGTAC & GTACA & 6004 & 1112 & 18.52098601 \\
\hline TGTAA & TTACA & 7396 & 1275 & 17.23904813 \\
\hline TACAC & GTGTA & 9484 & 1930 & 20.35006326 \\
\hline TACAA & TTGTA & 11205 & 1995 & 17.80455154 \\
\hline TACAG & CTGTA & 7098 & 927 & 13.06001691 \\
\hline TGTAT & ATACA & 5266 & 1288 & 24.45879225 \\
\hline GCGAG & CTCGC & 4857 & 227 & 4.673666873 \\
\hline CATAC & GTATG & 9806 & 1442 & 14.70528248 \\
\hline CATAA & TTATG & 11637 & 1958 & 16.82564235 \\
\hline GCGAC & GTCGC & 6264 & 619 & 9.881864623 \\
\hline CATAG & CTATG & 7338 & 788 & 10.73862088 \\
\hline GCGAA & TTCGC & 6398 & 537 & 8.39324789 \\
\hline GCGAT & ATCGC & 5005 & 518 & 10.34965035 \\
\hline CATAT & ATATG & 8573 & 1734 & 20.22629185 \\
\hline TCCAT & ATGGA & 6392 & 1755 & 27.45619524 \\
\hline CTCAT & ATGAG & 6712 & 1470 & 21.90107271 \\
\hline ACGAT & ATCGT & 7211 & 1384 & 19.19289974 \\
\hline CTCAC & GTGAG & 8596 & 1358 & 15.7980456 \\
\hline CTCAA & TTGAG & 9211 & 1459 & 15.83975681 \\
\hline TCCAA & TTGGA & 8576 & 1562 & 18.2136194 \\
\hline TCCAC & GTGGA & 7968 & 1855 & 23.28062249 \\
\hline ACGAA & TTCGT & 9581 & 1655 & 17.27377101 \\
\hline ACGAC & GTCGT & 8446 & 1434 & 16.97845134 \\
\hline ACGAG & CTCGT & 6463 & 906 & 14.01825778 \\
\hline GGCAT & ATGCC & 4982 & 902 & 18.10517864 \\
\hline GGCAG & CTGCC & 4514 & 349 & 7.731501994 \\
\hline GGCAC & GTGCC & 6718 & 1145 & 17.04376302 \\
\hline GGCAA & TTGCC & 6677 & 960 & 14.37771454 \\
\hline TTTAC & GTAAA & 7095 & 761 & 10.72586328 \\
\hline TTTAA & TTAAA & 9119 & 805 & 8.827722338 \\
\hline TTTAG & CTAAA & 5345 & 311 & 5.818521983 \\
\hline TTTAT & ATAAA & 6237 & 1106 & 17.7328844 \\
\hline GACAT & ATGTC & 7546 & 1577 & 20.89848927 \\
\hline
\end{tabular}




\begin{tabular}{|c|c|c|c|c|}
\hline AAAAT & ATTTT & 14761 & 2228 & 15.09382833 \\
\hline GACAA & TTGTC & 10120 & 1845 & 18.2312253 \\
\hline GACAC & GTGTC & 9068 & 1411 & 15.56021173 \\
\hline GACAG & CTGTC & 6479 & 784 & 12.10063281 \\
\hline AAAAA & TTTTT & 20472 & 2545 & 12.43161391 \\
\hline AAAAC & GTTTT & 15211 & 1719 & 11.30103215 \\
\hline AAAAG & CTTTT & 12273 & 1118 & 9.109427198 \\
\hline AGAAT & АТTCT & 8381 & 2182 & 26.03507935 \\
\hline CTAAG & CTTAG & 7422 & 1049 & 14.1336567 \\
\hline CTAAA & TTTAG & 12080 & 2327 & 19.26324503 \\
\hline CTAAC & GTTAG & 10057 & 1811 & 18.00735806 \\
\hline CTAAT & ATTAG & 8506 & 1939 & 22.79567364 \\
\hline AGAAG & СТTCT & 7424 & 1477 & 19.89493534 \\
\hline GTGAT & ATCAC & 4696 & 677 & 14.4165247 \\
\hline ATAAC & GTTAT & 11898 & 2041 & 17.15414355 \\
\hline TGAAT & ATTCA & 6984 & 1810 & 25.9163803 \\
\hline ATAAA & TTTAT & 16069 & 3204 & 19.93901301 \\
\hline ATAAG & CTTAT & 9405 & 1366 & 14.52418926 \\
\hline TGAAG & CTTCA & 6098 & 981 & 16.08724172 \\
\hline TGAAC & GTTCA & 7606 & 1684 & 22.14041546 \\
\hline ATAAT & ATTAT & 11059 & 2289 & 20.69807397 \\
\hline TGAAA & TTTCA & 9842 & 2037 & 20.6970128 \\
\hline GCCAC & GTGGC & 9528 & 1654 & 17.35936188 \\
\hline GCCAA & TTGGC & 9202 & 1512 & 16.43121061 \\
\hline GCCAG & CTGGC & 6720 & 829 & 12.33630952 \\
\hline GCCAT & ATGGC & 6888 & 1325 & 19.23635308 \\
\hline GTGAC & GTCAC & 5911 & 512 & 8.661816951 \\
\hline GTGAA & TTCAC & 6770 & 730 & 10.78286558 \\
\hline GTGAG & CTCAC & 4364 & 170 & 3.895508708 \\
\hline TTAAT & ATTAA & 8178 & 1658 & 20.2739056 \\
\hline AGAAC & GTTCT & 9087 & 1953 & 21.49224166 \\
\hline AGAAA & TTTCT & 11811 & 2706 & 22.91084582 \\
\hline TTAAC & GTTAA & 9047 & 1247 & 13.78357467 \\
\hline TTAAA & TTTAA & 12017 & 1469 & 12.22434884 \\
\hline TTAAG & CTTAA & 6965 & 602 & 8.64321608 \\
\hline CTGAT & ATCAG & 5904 & 1024 & 17.34417344 \\
\hline ACCAT & ATGGT & 9421 & 2328 & 24.71075257 \\
\hline TCGAC & GTCGA & 5677 & 992 & 17.47401797 \\
\hline TCGAG & CTCGA & 4519 & 512 & 11.32994025 \\
\hline CTGAG & CTCAG & 5407 & 316 & 5.844275939 \\
\hline CTGAC & GTCAG & 7505 & 836 & 11.13924051 \\
\hline CTGAA & TTCAG & 7983 & 1016 & 12.72704497 \\
\hline
\end{tabular}




\begin{tabular}{|c|c|c|c|c|}
\hline ACCAG & CTGGT & 8726 & 1596 & 18.29016732 \\
\hline TCGAT & ATCGA & 4709 & 1096 & 23.27458059 \\
\hline ACCAC & GTGGT & 11899 & 2616 & 21.98504076 \\
\hline TAGAT & ATCTA & 6148 & 1508 & 24.52830189 \\
\hline TAGAG & СТCTA & 5387 & 674 & 12.511602 \\
\hline TAGAC & GTCTA & 7169 & 1274 & 17.77095829 \\
\hline TAGAA & TTCTA & 8709 & 1315 & 15.09932254 \\
\hline ACCAA & TTGGT & 12899 & 2826 & 21.90867509 \\
\hline TGGAG & CTCCA & 3866 & 632 & 16.34764615 \\
\hline TGGAC & GTCCA & 5317 & 1049 & 19.72917058 \\
\hline TGGAT & ATCCA & 4137 & 1127 & 27.24196277 \\
\hline CCCAG & CTGGG & 9427 & 1651 & 17.51352498 \\
\hline GAGAT & АТСTC & 5492 & 731 & 13.31026948 \\
\hline CGGAT & ATCCG & 4793 & 647 & 13.49885249 \\
\hline CCCAC & GTGGG & 13548 & 3637 & 26.84529082 \\
\hline CCCAA & TTGGG & 12582 & 2740 & 21.77714195 \\
\hline CGGAG & CTCCG & 4599 & 391 & 8.501848228 \\
\hline GAGAG & СТСТС & 4960 & 431 & 8.689516129 \\
\hline CCCAT & ATGGG & 9603 & 2322 & 24.17994377 \\
\hline CGGAC & GTCCG & 6656 & 740 & 11.11778846 \\
\hline GAGAC & GTCTC & 6825 & 672 & 9.846153846 \\
\hline GGGAT & ATCCC & 3691 & 413 & 11.18937957 \\
\hline GGGAC & GTCCC & 4904 & 436 & 8.890701468 \\
\hline GGGAA & TTCCC & 5095 & 416 & 8.164867517 \\
\hline GGGAG & СТССC & 3602 & 139 & 3.85896724 \\
\hline TCGAA & TTCGA & 6431 & 902 & 14.02581247 \\
\hline AAGAA & TTCTT & 11776 & 1682 & 14.28328804 \\
\hline CGAAA & TTTCG & 9707 & 1787 & 18.40939528 \\
\hline TAAAG & CTTTA & 9085 & 952 & 10.47881123 \\
\hline TAAAA & TTTTA & 15354 & 1999 & 13.01940862 \\
\hline TAAAC & GTTTA & 11454 & 1749 & 15.26977475 \\
\hline TAAAT & ATTTA & 10722 & 2356 & 21.9735124 \\
\hline GCTAG & CTAGC & 5170 & 425 & 8.220502901 \\
\hline GCTAA & TTAGC & 7697 & 886 & 11.5109783 \\
\hline GCTAC & GTAGC & 6935 & 805 & 11.60778659 \\
\hline GCTAT & ATAGC & 5708 & 842 & 14.75122635 \\
\hline AGTAT & ATACT & 6238 & 1362 & 21.83392113 \\
\hline CAAAT & ATTTG & 10883 & 2079 & 19.10318846 \\
\hline CAAAC & GTTTG & 12681 & 1995 & 15.73219778 \\
\hline AGTAG & СТАCТ & 5511 & 781 & 14.17165669 \\
\hline CAAAA & TTTTG & 15191 & 2570 & 16.91791192 \\
\hline CAAAG & CTTTG & 9755 & 1203 & 12.33213737 \\
\hline
\end{tabular}




\begin{tabular}{|c|c|c|c|c|}
\hline AGTAC & GTACT & 7135 & 1281 & 17.95374912 \\
\hline AGTAA & TTACT & 8988 & 1675 & 18.63595906 \\
\hline GGAAA & TTTCC & 7522 & 1516 & 20.1542143 \\
\hline GGAAC & GTTCC & 5908 & 1199 & 20.29451591 \\
\hline GGAAG & CTTCC & 4904 & 861 & 17.55709625 \\
\hline GGAAT & ATTCC & 5310 & 1070 & 20.15065913 \\
\hline ATTAT & ATAAT & 8270 & 1574 & 19.03264813 \\
\hline ATTAC & GTAAT & 8827 & 1259 & 14.26305653 \\
\hline ATTAA & TTAAT & 12054 & 1957 & 16.2352746 \\
\hline ATTAG & CTAAT & 6869 & 721 & 10.49643325 \\
\hline AATAA & TTATT & 14945 & 2145 & 14.3526263 \\
\hline AATAC & GTATT & 11263 & 1358 & 12.05717837 \\
\hline TTGAT & ATCAA & 5169 & 949 & 18.35945057 \\
\hline AATAG & CTATT & 8725 & 838 & 9.604584527 \\
\hline TTGAA & TTCAA & 7505 & 734 & 9.780146569 \\
\hline TTGAC & GTCAA & 6262 & 706 & 11.27435324 \\
\hline AATAT & ATATT & 10679 & 1920 & 17.97921154 \\
\hline TTGAG & CTCAA & 4720 & 273 & 5.783898305 \\
\hline GTCAG & CTGAC & 4808 & 446 & 9.276206323 \\
\hline GTCAC & GTGAC & 6674 & 993 & 14.8786335 \\
\hline GTCAA & TTGAC & 7372 & 1120 & 15.19262073 \\
\hline CCGAT & ATCGG & 6406 & 1053 & 16.43771464 \\
\hline GTCAT & ATGAC & 5329 & 1045 & 19.60968287 \\
\hline CCGAC & GTCGG & 8901 & 1294 & 14.53769239 \\
\hline CCGAA & TTCGG & 8387 & 1028 & 12.2570645 \\
\hline CCGAG & CTCGG & 6168 & 556 & 9.014267185 \\
\hline CACAT & ATGTG & 9475 & 2267 & 23.92612137 \\
\hline CTTAT & ATAAG & 6797 & 1205 & 17.72840959 \\
\hline CTTAG & CTAAG & 5884 & 406 & 6.900067981 \\
\hline CTTAA & TTAAG & 9312 & 1191 & 12.78994845 \\
\hline CTTAC & GTAAG & 8019 & 967 & 12.05886021 \\
\hline CAGAA & TTCTG & 9414 & 1469 & 15.60441895 \\
\hline GGTAT & ATACC & 4359 & 609 & 13.97109429 \\
\hline GGTAA & TTACC & 6116 & 702 & 11.47809026 \\
\hline GGTAC & GTACC & 5126 & 606 & 11.8220835 \\
\hline GGTAG & CTACC & 3819 & 236 & 6.179628175 \\
\hline TGCAA & TTGCA & 7087 & 1683 & 23.74770707 \\
\hline TGCAC & GTGCA & 6750 & 1601 & 23.71851852 \\
\hline TGCAG & CTGCA & 4787 & 891 & 18.61290996 \\
\hline TGGAA & TTCCA & 5835 & 939 & 16.09254499 \\
\hline TGCAT & ATGCA & 5426 & 1670 & 30.77773682 \\
\hline ATCAT & ATGAT & 7421 & 1730 & 23.31222207 \\
\hline
\end{tabular}




\begin{tabular}{|c|c|c|c|c|}
\hline ATCAG & CTGAT & 6695 & 931 & 13.90589993 \\
\hline ATCAA & TTGAT & 10733 & 2147 & 20.00372682 \\
\hline ATCAC & GTGAT & 8579 & 1604 & 18.69681781 \\
\hline GCAAT & ATTGC & 7180 & 1279 & 17.81337047 \\
\hline GCAAG & CTTGC & 6827 & 822 & 12.04042771 \\
\hline GCAAA & TTTGC & 9882 & 1563 & 15.81663631 \\
\hline GCAAC & GTTGC & 8627 & 1299 & 15.057378 \\
\hline CAGAT & ATCTG & 6934 & 1214 & 17.50793193 \\
\hline TCAAT & ATTGA & 7235 & 1750 & 24.18797512 \\
\hline CAGAC & GTCTG & 8739 & 1248 & 14.28081016 \\
\hline CAGAG & CTCTG & 6392 & 708 & 11.07634543 \\
\hline TCAAC & GTTGA & 8473 & 1536 & 18.12817184 \\
\hline TCAAA & TTTGA & 10298 & 1629 & 15.81860555 \\
\hline TCAAG & CTTGA & 6718 & 901 & 13.41172968 \\
\hline \multirow[t]{3}{*}{ GAGAA } & ТTCTC & 7643 & 908 & 11.88015177 \\
\hline & & 2058018 & 335813 & \\
\hline & ERROR RATE & & 16.3173014 & \\
\hline
\end{tabular}




\begin{tabular}{|c|c|c|c|c|}
\hline pentamer & codon & observed & errors & error rate \\
\hline GAGAC & GTCTC & 559 & 7 & 1.252236136 \\
\hline СCTAT & ATAGG & 1131 & 15 & 1.326259947 \\
\hline CCTAA & TTAGG & 1792 & 25 & 1.395089286 \\
\hline CCTAC & GTAGG & 1383 & 21 & 1.518438178 \\
\hline CCTAG & CTAGG & 973 & 15 & 1.541623844 \\
\hline CGCAC & GTGCG & 1592 & 25 & 1.570351759 \\
\hline GATAG & СТАТC & 819 & 8 & 0.976800977 \\
\hline CGCAA & TTGCG & 1478 & 21 & 1.420838972 \\
\hline CGCAG & CTGCG & 813 & 9 & 1.10701107 \\
\hline GATAC & GTATC & 1194 & 14 & 1.172529313 \\
\hline GATAA & TTATC & 1488 & 23 & 1.545698925 \\
\hline GATAT & ATATC & 1227 & 9 & 0.733496333 \\
\hline CGCAT & ATGCG & 1271 & 13 & 1.02281668 \\
\hline AGCAA & TTGCT & 1372 & 29 & 2.113702624 \\
\hline TTCAT & ATGAA & 441 & 20 & 4.535147392 \\
\hline AGCAC & GTGCT & 1327 & 42 & 3.165033911 \\
\hline CCAAT & ATTGG & 1506 & 40 & 2.656042497 \\
\hline AGCAG & CTGCT & 694 & 23 & 3.314121037 \\
\hline CCAAA & TTTGG & 1937 & 25 & 1.290655653 \\
\hline CCAAC & GTTGG & 1961 & 39 & 1.988781234 \\
\hline TTCAA & TTGAA & 938 & 11 & 1.172707889 \\
\hline AGCAT & ATGCT & 1100 & 34 & 3.090909091 \\
\hline CCAAG & CTTGG & 1012 & 29 & 2.865612648 \\
\hline GAAAG & СTTTC & 589 & 8 & 1.358234295 \\
\hline GAAAC & GTTTC & 1185 & 20 & 1.687763713 \\
\hline GAAAA & TTTTC & 1164 & 16 & 1.374570447 \\
\hline AACAG & CTGTT & 871 & 18 & 2.066590126 \\
\hline TATAT & ATATA & 299 & 9 & 3.010033445 \\
\hline AACAC & GTGTT & 1653 & 43 & 2.601330913 \\
\hline AACAA & TTGTT & 1778 & 26 & 1.46231721 \\
\hline GAAAT & ATTTC & 1070 & 17 & 1.588785047 \\
\hline TATAG & CTATA & 430 & 5 & 1.162790698 \\
\hline AACAT & ATGTT & 1452 & 35 & 2.41046832 \\
\hline TATAA & TTATA & 871 & 8 & 0.918484501 \\
\hline TATAC & GTATA & 436 & 6 & 1.376146789 \\
\hline ACTAT & ATAGT & 802 & 19 & 2.369077307 \\
\hline ACTAC & GTAGT & 930 & 24 & 2.580645161 \\
\hline ACTAA & TTAGT & 1330 & 25 & 1.879699248 \\
\hline ACTAG & CTAGT & 654 & 17 & 2.599388379 \\
\hline CACAT & ATGTG & 2090 & 51 & 2.440191388 \\
\hline CACAG & CTGTG & 1231 & 26 & 2.112103981 \\
\hline CACAA & TTGTG & 2305 & 39 & 1.69197397 \\
\hline
\end{tabular}




\begin{tabular}{|c|c|c|c|c|}
\hline CACAC & GTGTG & 2480 & 47 & 1.89516129 \\
\hline ATGAT & ATCAT & 668 & 9 & 1.347305389 \\
\hline ATGAA & TTCAT & 959 & 22 & 2.294056309 \\
\hline ATGAC & GTCAT & 870 & 25 & 2.873563218 \\
\hline ATGAG & СТCAT & 528 & 9 & 1.704545455 \\
\hline CGTAT & ATACG & 859 & 14 & 1.629802095 \\
\hline CGTAG & CTACG & 681 & 10 & 1.468428781 \\
\hline CGTAA & TTACG & 1266 & 22 & 1.737756714 \\
\hline CGTAC & GTACG & 1038 & 16 & 1.541425819 \\
\hline GTAAT & ATTAC & 1242 & 19 & 1.52979066 \\
\hline GTAAA & TTTAC & 1489 & 34 & 2.283411686 \\
\hline GTAAC & GTTAC & 1431 & 30 & 2.096436059 \\
\hline GTAAG & CTTAC & 804 & 16 & 1.990049751 \\
\hline AGGAA & ТTCCT & 583 & 6 & 1.02915952 \\
\hline AGGAC & GTCCT & 585 & 17 & 2.905982906 \\
\hline TCTAC & GTAGA & 289 & 18 & 6.228373702 \\
\hline TCTAA & TTAGA & 631 & 9 & 1.426307448 \\
\hline TCTAG & CTAGA & 321 & 6 & 1.869158879 \\
\hline AGGAT & АТCCT & 392 & 16 & 4.081632653 \\
\hline TCCAG & CTGGA & 547 & 14 & 2.559414991 \\
\hline TCTAT & ATAGA & 234 & 11 & 4.700854701 \\
\hline ACAAC & GTTGT & 1266 & 20 & 1.579778831 \\
\hline ACAAA & TTTGT & 1498 & 49 & 3.271028037 \\
\hline ACAAG & CTTGT & 671 & 29 & 4.321907601 \\
\hline GTTAA & TTAAC & 1577 & 17 & 1.077996195 \\
\hline GTTAC & GTAAC & 1188 & 9 & 0.757575758 \\
\hline GGTAG & CTACC & 503 & 15 & 2.982107356 \\
\hline AGGAG & СТССТ & 317 & 6 & 1.892744479 \\
\hline GTTAG & CTAAC & 879 & 6 & 0.682593857 \\
\hline ACAAT & ATTGT & 1017 & 42 & 4.12979351 \\
\hline GTTAT & ATAAC & 1208 & 17 & 1.407284768 \\
\hline TTCAG & CTGAA & 526 & 7 & 1.330798479 \\
\hline TTCAC & GTGAA & 601 & 22 & 3.660565724 \\
\hline AAGAC & GTCTT & 487 & 16 & 3.285420945 \\
\hline CGAAG & CTTCG & 625 & 16 & 2.56 \\
\hline CGAAA & TTTCG & 1291 & 16 & 1.239349342 \\
\hline CGAAC & GTTCG & 1326 & 26 & 1.960784314 \\
\hline CGAAT & ATTCG & 974 & 16 & 1.642710472 \\
\hline TCCAA & TTGGA & 949 & 32 & 3.371970495 \\
\hline AAGAT & ATCTT & 334 & 9 & 2.694610778 \\
\hline TACAT & ATGTA & 484 & 14 & 2.892561983 \\
\hline TGTAG & CTACA & 442 & 9 & 2.036199095 \\
\hline TGTAC & GTACA & 504 & 14 & 2.777777778 \\
\hline TGTAA & TTACA & 715 & 8 & 1.118881119 \\
\hline
\end{tabular}




\begin{tabular}{|c|c|c|c|c|}
\hline TACAC & GTGTA & 690 & 25 & 3.623188406 \\
\hline TACAA & TTGTA & 991 & 18 & 1.816347124 \\
\hline TACAG & CTGTA & 502 & 10 & 1.992031873 \\
\hline TGTAT & ATACA & 429 & 13 & 3.03030303 \\
\hline GCGAG & CTCGC & 267 & 2 & 0.74906367 \\
\hline CATAC & GTATG & 1830 & 27 & 1.475409836 \\
\hline CATAA & TTATG & 2128 & 27 & 1.268796992 \\
\hline GCGAC & GTCGC & 477 & 10 & 2.096436059 \\
\hline CATAG & CTATG & 1040 & 7 & 0.673076923 \\
\hline GCGAA & TTCGC & 529 & 9 & 1.701323251 \\
\hline GCGAT & ATCGC & 382 & 11 & 2.879581152 \\
\hline CATAT & ATATG & 1640 & 18 & 1.097560976 \\
\hline TCCAT & ATGGA & 385 & 36 & 9.350649351 \\
\hline CTCAT & ATGAG & 1610 & 28 & 1.739130435 \\
\hline ACGAT & ATCGT & 338 & 15 & 4.437869822 \\
\hline CTCAC & GTGAG & 1817 & 31 & 1.706108971 \\
\hline CTCAA & TTGAG & 1990 & 30 & 1.507537688 \\
\hline CTCAG & CTGAG & 1208 & 15 & 1.241721854 \\
\hline TCCAC & GTGGA & 645 & 69 & 10.69767442 \\
\hline ACGAA & TTCGT & 553 & 13 & 2.350813743 \\
\hline ACGAC & GTCGT & 405 & 20 & 4.938271605 \\
\hline ACGAG & CTCGT & 209 & 11 & 5.263157895 \\
\hline GGCAT & ATGCC & 920 & 13 & 1.413043478 \\
\hline GGCAG & CTGCC & 706 & 17 & 2.407932011 \\
\hline GGCAC & GTGCC & 1076 & 18 & 1.672862454 \\
\hline GGCAA & TTGCC & 1168 & 25 & 2.140410959 \\
\hline TTTAC & GTAAA & 337 & 4 & 1.18694362 \\
\hline TTTAA & TTAAA & 692 & 6 & 0.867052023 \\
\hline TTTAG & CTAAA & 350 & 1 & 0.285714286 \\
\hline TTTAT & ATAAA & 297 & 5 & 1.683501684 \\
\hline GACAT & ATGTC & 1415 & 28 & 1.978798587 \\
\hline AAAAT & ATTTT & 928 & 18 & 1.939655172 \\
\hline GACAA & TTGTC & 1716 & 42 & 2.447552448 \\
\hline GACAC & GTGTC & 1707 & 33 & 1.933216169 \\
\hline GACAG & CTGTC & 978 & 20 & 2.044989775 \\
\hline AAAAA & TTTTT & 1245 & 21 & 1.686746988 \\
\hline AAAAC & GTTTT & 1105 & 15 & 1.357466063 \\
\hline AAAAG & CTTTT & 540 & 15 & 2.777777778 \\
\hline GTGAA & TTCAC & 875 & 11 & 1.257142857 \\
\hline CTAAG & CTTAG & 960 & 14 & 1.458333333 \\
\hline CTAAA & TTTAG & 1645 & 27 & 1.641337386 \\
\hline CTAAC & GTTAG & 1532 & 23 & 1.501305483 \\
\hline CTAAT & ATTAG & 1347 & 28 & 2.078693393 \\
\hline AGAAA & TTTCT & 1091 & 22 & 2.016498625 \\
\hline
\end{tabular}




\begin{tabular}{|c|c|c|c|c|}
\hline ATAAC & GTTAT & 1555 & 16 & 1.028938907 \\
\hline TGAAT & ATTCA & 549 & 13 & 2.367941712 \\
\hline ATAAA & TTTAT & 1896 & 22 & 1.160337553 \\
\hline ATAAG & CTTAT & 962 & 21 & 2.182952183 \\
\hline TGAAG & CTTCA & 489 & 4 & 0.81799591 \\
\hline TGAAC & GTTCA & 774 & 11 & 1.42118863 \\
\hline ATAAT & ATTAT & 1363 & 25 & 1.834189288 \\
\hline TGAAA & TTTCA & 989 & 18 & 1.820020222 \\
\hline GCCAC & GTGGC & 1795 & 19 & 1.058495822 \\
\hline GCCAA & TTGGC & 1962 & 49 & 2.49745158 \\
\hline GCCAG & CTGGC & 1055 & 28 & 2.654028436 \\
\hline GCCAT & ATGGC & 1379 & 20 & 1.450326323 \\
\hline GTGAC & GTCAC & 874 & 10 & 1.14416476 \\
\hline AGAAT & ATTCT & 848 & 20 & 2.358490566 \\
\hline GTGAG & CTCAC & 515 & 9 & 1.747572816 \\
\hline TTAAT & ATTAA & 302 & 6 & 1.986754967 \\
\hline AGAAG & СТTCT & 471 & 7 & 1.486199575 \\
\hline AGAAC & GTTCT & 1023 & 14 & 1.368523949 \\
\hline GTGAT & ATCAC & 780 & 7 & 0.897435897 \\
\hline TCGAA & TTCGA & 268 & 4 & 1.492537313 \\
\hline TTAAC & GTTAA & 436 & 9 & 2.064220183 \\
\hline TTAAA & TTTAA & 932 & 20 & 2.145922747 \\
\hline TTAAG & CTTAA & 380 & 2 & 0.526315789 \\
\hline CTGAT & ATCAG & 622 & 6 & 0.964630225 \\
\hline ACCAT & ATGGT & 1193 & 47 & 3.939647946 \\
\hline TCGAC & GTCGA & 168 & 12 & 7.142857143 \\
\hline TCGAG & CTCGA & 162 & 5 & 3.086419753 \\
\hline CTGAG & CTCAG & 498 & 6 & 1.204819277 \\
\hline CTGAC & GTCAG & 855 & 12 & 1.403508772 \\
\hline CTGAA & TTCAG & 926 & 9 & 0.971922246 \\
\hline ACCAG & CTGGT & 905 & 19 & 2.099447514 \\
\hline TAGAT & ATCTA & 114 & 9 & 7.894736842 \\
\hline ATCAA & TTGAT & 1923 & 21 & 1.092043682 \\
\hline TAGAG & CTCTA & 134 & 3 & 2.23880597 \\
\hline TAGAC & GTCTA & 162 & 7 & 4.320987654 \\
\hline TAGAA & TTCTA & 231 & 3 & 1.298701299 \\
\hline ACCAA & TTGGT & 1771 & 38 & 2.145680407 \\
\hline TGGAG & СТССА & 192 & 0 & 0 \\
\hline TGGAA & TTCCA & 411 & 9 & 2.189781022 \\
\hline TGGAC & GTCCA & 284 & 9 & 3.169014085 \\
\hline ACCAC & GTGGT & 1536 & 49 & 3.190104167 \\
\hline TGGAT & ATCCA & 198 & 9 & 4.545454545 \\
\hline CCCAG & CTGGG & 1529 & 27 & 1.765860039 \\
\hline GAGAT & ATCTC & 419 & 4 & 0.954653938 \\
\hline
\end{tabular}




\begin{tabular}{|c|c|c|c|c|}
\hline CGGAT & ATCCG & 450 & 10 & 2.222222222 \\
\hline CCCAC & GTGGG & 2553 & 52 & 2.036819428 \\
\hline CCCAA & TTGGG & 2595 & 40 & 1.541425819 \\
\hline CGGAG & CTCCG & 361 & 8 & 2.216066482 \\
\hline GAGAG & СТСТС & 303 & 5 & 1.650165017 \\
\hline CCCAT & ATGGG & 1853 & 42 & 2.266594711 \\
\hline CGGAC & GTCCG & 648 & 11 & 1.697530864 \\
\hline CGGAA & TTCCG & 667 & 10 & 1.499250375 \\
\hline GGGAT & ATCCC & 446 & 8 & 1.793721973 \\
\hline GGGAC & GTCCC & 478 & 15 & 3.138075314 \\
\hline GGGAA & TTCCC & 567 & 13 & 2.292768959 \\
\hline GGGAG & СТCСC & 308 & 10 & 3.246753247 \\
\hline AAGAA & TTCTT & 666 & 8 & 1.201201201 \\
\hline AAGAG & СТCTT & 242 & 3 & 1.239669421 \\
\hline TAAAG & CTTTA & 351 & 1 & 0.284900285 \\
\hline TAAAA & TTTTA & 877 & 14 & 1.596351197 \\
\hline TAAAC & GTTTA & 553 & 13 & 2.350813743 \\
\hline TAAAT & ATTTA & 361 & 5 & 1.385041551 \\
\hline GCTAG & CTAGC & 664 & 13 & 1.957831325 \\
\hline GCTAA & TTAGC & 1153 & 26 & 2.25498699 \\
\hline GCTAC & GTAGC & 881 & 18 & 2.043132804 \\
\hline GCTAT & ATAGC & 828 & 16 & 1.93236715 \\
\hline AGTAT & ATACT & 873 & 21 & 2.405498282 \\
\hline CAAAT & ATTTG & 1573 & 24 & 1.52574698 \\
\hline CAAAC & GTTTG & 1861 & 25 & 1.343363783 \\
\hline AGTAG & СТАСТ & 568 & 10 & 1.76056338 \\
\hline CAAAA & TTTTG & 1778 & 26 & 1.46231721 \\
\hline CAAAG & CTTTG & 847 & 16 & 1.889020071 \\
\hline AGTAC & GTACT & 933 & 12 & 1.286173633 \\
\hline AGTAA & TTACT & 1198 & 26 & 2.170283806 \\
\hline GGAAA & TTTCC & 819 & 27 & 3.296703297 \\
\hline GGAAC & GTTCC & 674 & 14 & 2.077151335 \\
\hline GGAAG & CTTCC & 452 & 8 & 1.769911504 \\
\hline GGAAT & ATTCC & 716 & 16 & 2.234636872 \\
\hline ATTAT & ATAAT & 1381 & 23 & 1.665459812 \\
\hline ATTAC & GTAAT & 1422 & 23 & 1.617440225 \\
\hline ATTAA & TTAAT & 1918 & 29 & 1.511991658 \\
\hline ATTAG & CTAAT & 1023 & 12 & 1.173020528 \\
\hline AATAA & TTATT & 1774 & 20 & 1.127395716 \\
\hline AATAC & GTATT & 1350 & 27 & 2 \\
\hline TTGAT & ATCAA & 149 & 4 & 2.684563758 \\
\hline AATAG & CTATT & 880 & 14 & 1.590909091 \\
\hline TTGAA & TTCAA & 350 & 4 & 1.142857143 \\
\hline TTGAC & GTCAA & 220 & 2 & 0.909090909 \\
\hline
\end{tabular}




\begin{tabular}{|c|c|c|c|c|}
\hline AATAT & ATATT & 1252 & 15 & 1.198083067 \\
\hline TTGAG & CTCAA & 178 & 5 & 2.808988764 \\
\hline GTCAG & CTGAC & 1003 & 17 & 1.694915254 \\
\hline GTCAC & GTGAC & 1617 & 23 & 1.422387137 \\
\hline GTCAA & TTGAC & 1756 & 33 & 1.879271071 \\
\hline CCGAT & ATCGG & 524 & 9 & 1.717557252 \\
\hline GTCAT & ATGAC & 1344 & 27 & 2.008928571 \\
\hline CCGAC & GTCGG & 641 & 14 & 2.184087363 \\
\hline CCGAA & TTCGG & 775 & 11 & 1.419354839 \\
\hline CCGAG & CTCGG & 331 & 7 & 2.114803625 \\
\hline СТTAT & ATAAG & 1233 & 14 & 1.135442011 \\
\hline CTTAG & CTAAG & 1005 & 11 & 1.094527363 \\
\hline CTTAA & TTAAG & 1903 & 17 & 0.893326327 \\
\hline CTTAC & GTAAG & 1402 & 13 & 0.92724679 \\
\hline GGTAT & ATACC & 686 & 12 & 1.749271137 \\
\hline GGTAA & TTACC & 895 & 14 & 1.56424581 \\
\hline GGTAC & GTACC & 687 & 10 & 1.455604076 \\
\hline TGCAA & TTGCA & 807 & 13 & 1.610904585 \\
\hline TGCAC & GTGCA & 720 & 34 & 4.722222222 \\
\hline TGCAG & CTGCA & 531 & 8 & 1.506591337 \\
\hline TGCAT & ATGCA & 548 & 25 & 4.562043796 \\
\hline ATCAT & ATGAT & 1582 & 31 & 1.95954488 \\
\hline ATCAG & CTGAT & 1072 & 24 & 2.23880597 \\
\hline ATCAC & GTGAT & 1805 & 38 & 2.105263158 \\
\hline GCAAT & ATTGC & 1096 & 24 & 2.189781022 \\
\hline GCAAG & CTTGC & 711 & 18 & 2.53164557 \\
\hline GCAAA & TTTGC & 1311 & 23 & 1.754385965 \\
\hline GCAAC & GTTGC & 1325 & 33 & 2.490566038 \\
\hline TCGAT & ATCGA & 149 & 12 & 8.053691275 \\
\hline CAGAT & ATCTG & 565 & 13 & 2.300884956 \\
\hline TCAAT & ATTGA & 385 & 13 & 3.376623377 \\
\hline CAGAA & TTCTG & 931 & 21 & 2.255639098 \\
\hline CAGAC & GTCTG & 847 & 11 & 1.298701299 \\
\hline CAGAG & CTCTG & 444 & 14 & 3.153153153 \\
\hline TCAAC & GTTGA & 546 & 19 & 3.47985348 \\
\hline TCAAA & TTTGA & 974 & 19 & 1.950718686 \\
\hline TCAAG & CTTGA & 503 & 9 & 1.789264414 \\
\hline \multirow[t]{2}{*}{ GAGAA } & TTCTC & 577 & 13 & 2.253032929 \\
\hline & & 240177 & 4594 & \\
\hline
\end{tabular}

ERROR RATE = 


\begin{tabular}{|c|c|c|c|c|}
\hline pentamer & codon & observed & errors & error rate \\
\hline TAAAG & CTTTA & 288 & 9 & 3.125 \\
\hline TTCAC & GTGAA & 664 & 15 & 2.259036145 \\
\hline GAGAA & TTCTC & 510 & 17 & 3.333333333 \\
\hline AGTAT & ATACT & 824 & 22 & 2.669902913 \\
\hline CTAAG & CTTAG & 522 & 13 & 2.490421456 \\
\hline CCTAT & ATAGG & 962 & 19 & 1.975051975 \\
\hline CTAAA & TTTAG & 1063 & 24 & 2.257761054 \\
\hline CAAAT & ATTTG & 1462 & 27 & 1.846785226 \\
\hline GAGAC & GTCTC & 603 & 8 & 1.326699834 \\
\hline TCCAG & CTGGA & 729 & 14 & 1.920438957 \\
\hline CTAAT & ATTAG & 934 & 31 & 3.319057816 \\
\hline AGTAG & СТACT & 508 & 20 & 3.937007874 \\
\hline CAAAA & TTTTG & 1123 & 17 & 1.513802315 \\
\hline ССТАC & GTAGG & 1388 & 29 & 2.089337176 \\
\hline CAAAG & CTTTG & 623 & 16 & 2.568218299 \\
\hline AGTAC & GTACT & 800 & 22 & 2.75 \\
\hline CCTAG & CTAGG & 980 & 13 & 1.326530612 \\
\hline TAGAC & GTCTA & 225 & 7 & 3.111111111 \\
\hline CGCAC & GTGCG & 1548 & 26 & 1.679586563 \\
\hline GATAG & CTATC & 567 & 9 & 1.587301587 \\
\hline CGCAA & TTGCG & 1522 & 32 & 2.102496715 \\
\hline CGCAG & CTGCG & 776 & 25 & 3.221649485 \\
\hline GATAC & GTATC & 824 & 12 & 1.45631068 \\
\hline GGAAG & CTTCC & 344 & 8 & 2.325581395 \\
\hline GATAA & TTATC & 994 & 10 & 1.006036217 \\
\hline GATAT & ATATC & 810 & 14 & 1.728395062 \\
\hline GGAAT & ATTCC & 554 & 10 & 1.805054152 \\
\hline CGCAT & ATGCG & 1426 & 27 & 1.893408135 \\
\hline AGCAA & TTGCT & 1072 & 40 & 3.731343284 \\
\hline TTCAT & ATGAA & 580 & 21 & 3.620689655 \\
\hline AGCAC & GTGCT & 1206 & 41 & 3.399668325 \\
\hline CGAAA & TTTCG & 954 & 20 & 2.096436059 \\
\hline CCAAT & ATTGG & 1426 & 33 & 2.314165498 \\
\hline CGAAC & GTTCG & 1054 & 25 & 2.371916509 \\
\hline ATTAT & ATAAT & 906 & 16 & 1.766004415 \\
\hline AAGAT & АTCTT & 399 & 10 & 2.506265664 \\
\hline CCAAA & TTTGG & 1615 & 41 & 2.53869969 \\
\hline CGAAT & ATTCG & 956 & 23 & 2.405857741 \\
\hline TTCAG & CTGAA & 436 & 5 & 1.146788991 \\
\hline ATAAA & TTTAT & 1018 & 43 & 4.223968566 \\
\hline ATTAG & CTAAT & 544 & 11 & 2.022058824 \\
\hline AGCAT & ATGCT & 1081 & 39 & 3.607770583 \\
\hline CCAAG & CTTGG & 902 & 30 & 3.32594235 \\
\hline
\end{tabular}




\begin{tabular}{|c|c|c|c|c|}
\hline AATAA & TTATT & 888 & 21 & 2.364864865 \\
\hline AGTAA & TTACT & 867 & 24 & 2.76816609 \\
\hline CTAAC & GTTAG & 1041 & 20 & 1.921229587 \\
\hline TAGAA & TTCTA & 273 & 3 & 1.098901099 \\
\hline GAAAG & CTTTC & 352 & 4 & 1.136363636 \\
\hline ATAAC & GTTAT & 1150 & 34 & 2.956521739 \\
\hline TGAAT & ATTCA & 626 & 16 & 2.555910543 \\
\hline AATAC & GTATT & 837 & 20 & 2.38948626 \\
\hline GAAAC & GTTTC & 899 & 23 & 2.55839822 \\
\hline ATAAG & СTTAT & 560 & 16 & 2.857142857 \\
\hline GAAAA & TTTTC & 694 & 21 & 3.025936599 \\
\hline AATAG & CTATT & 509 & 13 & 2.554027505 \\
\hline CCCAC & GTGGG & 2559 & 89 & 3.477921063 \\
\hline TATAT & ATATA & 363 & 11 & 3.03030303 \\
\hline AACAC & GTGTT & 1464 & 43 & 2.93715847 \\
\hline AACAA & TTGTT & 1371 & 49 & 3.574033552 \\
\hline TTGAA & TTCAA & 430 & 9 & 2.093023256 \\
\hline TGAAG & CTTCA & 410 & 8 & 1.951219512 \\
\hline TTGAC & GTCAA & 380 & 6 & 1.578947368 \\
\hline GAAAT & ATTTC & 758 & 20 & 2.638522427 \\
\hline AATAT & ATATT & 857 & 13 & 1.516919487 \\
\hline TGAAC & GTTCA & 832 & 16 & 1.923076923 \\
\hline ATAAT & ATTAT & 949 & 30 & 3.161222339 \\
\hline TGAAA & TTTCA & 772 & 20 & 2.590673575 \\
\hline TATAG & CTATA & 277 & 5 & 1.805054152 \\
\hline TCTAT & ATAGA & 346 & 10 & 2.89017341 \\
\hline TATAA & TTATA & 527 & 14 & 2.65654649 \\
\hline TATAC & GTATA & 414 & 9 & 2.173913043 \\
\hline GCCAC & GTGGC & 1782 & 27 & 1.515151515 \\
\hline GTCAG & CTGAC & 793 & 9 & 1.134930643 \\
\hline GCCAA & TTGGC & 1891 & 34 & 1.797990481 \\
\hline GCCAG & CTGGC & 1067 & 23 & 2.155576382 \\
\hline GTCAC & GTGAC & 1374 & 25 & 1.819505095 \\
\hline TACAT & ATGTA & 629 & 23 & 3.656597774 \\
\hline GTCAA & TTGAC & 1463 & 21 & 1.435406699 \\
\hline TGTAG & CTACA & 465 & 3 & 0.64516129 \\
\hline TGTAC & GTACA & 639 & 16 & 2.503912363 \\
\hline TGTAA & TTACA & 706 & 14 & 1.983002833 \\
\hline CCGAT & ATCGG & 697 & 9 & 1.291248207 \\
\hline TACAC & GTGTA & 841 & 25 & 2.972651605 \\
\hline GTCAT & ATGAC & 1070 & 20 & 1.869158879 \\
\hline TACAA & TTGTA & 892 & 21 & 2.35426009 \\
\hline TACAG & CTGTA & 475 & 12 & 2.526315789 \\
\hline CСТAA & TTAGG & 1586 & 22 & 1.387137453 \\
\hline CCGAC & GTCGG & 988 & 25 & 2.530364372 \\
\hline
\end{tabular}




\begin{tabular}{|c|c|c|c|c|}
\hline CCGAA & TTCGG & 955 & 18 & 1.884816754 \\
\hline TGTAT & ATACA & 448 & 6 & 1.339285714 \\
\hline CCGAG & CTCGG & 397 & 9 & 2.267002519 \\
\hline GTGAC & GTCAC & 961 & 12 & 1.248699272 \\
\hline AGAAT & АТTCT & 643 & 23 & 3.576982893 \\
\hline GTGAG & CTCAC & 469 & 4 & 0.852878465 \\
\hline GCGAG & CTCGC & 331 & 5 & 1.510574018 \\
\hline CATAC & GTATG & 1307 & 28 & 2.142310635 \\
\hline CATAA & TTATG & 1398 & 32 & 2.288984263 \\
\hline GCGAC & GTCGC & 648 & 11 & 1.697530864 \\
\hline CATAG & CTATG & 809 & 6 & 0.741656366 \\
\hline GCGAA & TTCGC & 567 & 9 & 1.587301587 \\
\hline TTAAT & ATTAA & 335 & 10 & 2.985074627 \\
\hline AGAAG & СТTCT & 309 & 19 & 6.148867314 \\
\hline CGTAG & CTACG & 698 & 20 & 2.865329513 \\
\hline AGAAC & GTTCT & 666 & 26 & 3.903903904 \\
\hline AGAAA & TTTCT & 670 & 40 & 5.970149254 \\
\hline TCGAA & TTCGA & 470 & 12 & 2.553191489 \\
\hline TTAAC & GTTAA & 473 & 15 & 3.171247357 \\
\hline TTAAA & TTTAA & 619 & 12 & 1.938610662 \\
\hline GCGAT & ATCGC & 468 & 11 & 2.35042735 \\
\hline TTAAG & CTTAA & 279 & 6 & 2.150537634 \\
\hline CATAT & ATATG & 1396 & 24 & 1.719197708 \\
\hline CTGAT & ATCAG & 671 & 9 & 1.341281669 \\
\hline TTGAG & CTCAA & 218 & 5 & 2.293577982 \\
\hline ACCAT & ATGGT & 1552 & 35 & 2.255154639 \\
\hline TCGAC & GTCGA & 389 & 11 & 2.827763496 \\
\hline TCGAG & CTCGA & 236 & 3 & 1.271186441 \\
\hline CTGAG & CTCAG & 458 & 6 & 1.310043668 \\
\hline CTGAC & GTCAG & 979 & 10 & 1.02145046 \\
\hline CTGAA & TTCAG & 845 & 14 & 1.656804734 \\
\hline ACCAG & CTGGT & 1055 & 42 & 3.981042654 \\
\hline ACCAA & TTGGT & 2031 & 63 & 3.101920236 \\
\hline ACCAC & GTGGT & 1989 & 68 & 3.418803419 \\
\hline TCCAT & ATGGA & 702 & 30 & 4.273504274 \\
\hline TAGAT & ATCTA & 157 & 7 & 4.458598726 \\
\hline AACAT & ATGTT & 1340 & 33 & 2.462686567 \\
\hline GGTAT & ATACC & 569 & 6 & 1.054481547 \\
\hline СТCAT & ATGAG & 1115 & 28 & 2.511210762 \\
\hline ACGAT & ATCGT & 518 & 21 & 4.054054054 \\
\hline GGTAG & CTACC & 520 & 4 & 0.769230769 \\
\hline GGTAA & TTACC & 852 & 18 & 2.112676056 \\
\hline ACTAA & TTAGT & 1231 & 37 & 3.005686434 \\
\hline TCCAA & TTGGA & 1180 & 29 & 2.457627119 \\
\hline TCCAC & GTGGA & 1007 & 48 & 4.766633565 \\
\hline
\end{tabular}




\begin{tabular}{|c|c|c|c|c|}
\hline ACGAA & TTCGT & 678 & 22 & 3.244837758 \\
\hline ACGAC & GTCGT & 756 & 17 & 2.248677249 \\
\hline GGAAC & GTTCC & 449 & 15 & 3.340757238 \\
\hline ACGAG & CTCGT & 312 & 15 & 4.807692308 \\
\hline TGCAA & TTGCA & 747 & 20 & 2.677376171 \\
\hline TGCAC & GTGCA & 890 & 31 & 3.483146067 \\
\hline TGCAG & CTGCA & 607 & 17 & 2.800658979 \\
\hline CTTAT & ATAAG & 822 & 7 & 0.851581509 \\
\hline GGCAT & ATGCC & 826 & 23 & 2.784503632 \\
\hline CTCAG & CTGAG & 788 & 18 & 2.284263959 \\
\hline TGCAT & ATGCA & 756 & 24 & 3.174603175 \\
\hline GGCAG & CTGCC & 542 & 9 & 1.660516605 \\
\hline GGCAC & GTGCC & 1058 & 37 & 3.497164461 \\
\hline CTTAG & CTAAG & 614 & 6 & 0.977198697 \\
\hline GGCAA & TTGCC & 1071 & 15 & 1.400560224 \\
\hline CACAT & ATGTG & 2012 & 43 & 2.137176938 \\
\hline AAGAA & TTCTT & 518 & 20 & 3.861003861 \\
\hline CTTAA & TTAAG & 1052 & 23 & 2.186311787 \\
\hline TGGAG & СТССА & 268 & 2 & 0.746268657 \\
\hline TGGAA & TTCCA & 472 & 6 & 1.271186441 \\
\hline TGGAC & GTCCA & 458 & 8 & 1.746724891 \\
\hline CACAG & CTGTG & 1091 & 36 & 3.299725023 \\
\hline CACAA & TTGTG & 2055 & 63 & 3.065693431 \\
\hline CTTAC & GTAAG & 809 & 20 & 2.472187886 \\
\hline CACAC & GTGTG & 2132 & 41 & 1.923076923 \\
\hline TGGAT & ATCCA & 313 & 12 & 3.833865815 \\
\hline GACAC & GTGTC & 1478 & 31 & 2.097428958 \\
\hline CCCAG & CTGGG & 1444 & 53 & 3.670360111 \\
\hline GAGAT & АТСТC & 431 & 9 & 2.088167053 \\
\hline CGGAT & ATCCG & 629 & 13 & 2.066772655 \\
\hline ATGAT & ATCAT & 790 & 15 & 1.898734177 \\
\hline CCCAA & TTGGG & 2727 & 54 & 1.98019802 \\
\hline TTTAC & GTAAA & 316 & 12 & 3.797468354 \\
\hline CAAAC & GTTTG & 1340 & 35 & 2.611940299 \\
\hline TTTAA & TTAAA & 493 & 8 & 1.622718053 \\
\hline TTTAG & CTAAA & 270 & 7 & 2.592592593 \\
\hline CGGAG & CTCCG & 325 & 6 & 1.846153846 \\
\hline ATGAA & TTCAT & 938 & 22 & 2.345415778 \\
\hline GAGAG & СТСТС & 283 & 9 & 3.180212014 \\
\hline ATGAC & GTCAT & 1075 & 20 & 1.860465116 \\
\hline CGGAC & GTCCG & 716 & 18 & 2.51396648 \\
\hline CGGAA & TTCCG & 638 & 14 & 2.194357367 \\
\hline ATGAG & СТCAT & 507 & 13 & 2.564102564 \\
\hline TTTAT & ATAAA & 313 & 5 & 1.597444089 \\
\hline CGTAT & ATACG & 1034 & 12 & 1.160541586 \\
\hline
\end{tabular}




\begin{tabular}{|c|c|c|c|c|}
\hline GACAT & ATGTC & 1218 & 20 & 1.642036125 \\
\hline GGGAT & ATCCC & 450 & 15 & 3.333333333 \\
\hline ATCAT & ATGAT & 1412 & 26 & 1.841359773 \\
\hline AAAAT & ATTTT & 702 & 18 & 2.564102564 \\
\hline GACAA & TTGTC & 1399 & 27 & 1.929949964 \\
\hline TTGAT & ATCAA & 247 & 11 & 4.453441296 \\
\hline GGGAA & TTCCC & 499 & 11 & 2.204408818 \\
\hline GGGAC & GTCCC & 520 & 14 & 2.692307692 \\
\hline GGGAG & СТССС & 294 & 6 & 2.040816327 \\
\hline CGTAA & TTACG & 1270 & 29 & 2.283464567 \\
\hline GACAG & CTGTC & 718 & 16 & 2.228412256 \\
\hline CGTAC & GTACG & 1155 & 13 & 1.125541126 \\
\hline AAAAA & TTTTT & 602 & 27 & 4.485049834 \\
\hline AACAG & CTGTT & 695 & 22 & 3.165467626 \\
\hline AAAAC & GTTTT & 761 & 14 & 1.839684625 \\
\hline ATCAG & CTGAT & 768 & 28 & 3.645833333 \\
\hline ATCAA & TTGAT & 1413 & 33 & 2.335456476 \\
\hline AAAAG & СТTTT & 332 & 9 & 2.710843373 \\
\hline ATCAC & GTGAT & 1461 & 36 & 2.464065708 \\
\hline AAGAC & GTCTT & 496 & 11 & 2.217741935 \\
\hline ACTAT & ATAGT & 861 & 17 & 1.974448316 \\
\hline GTAAT & ATTAC & 950 & 30 & 3.157894737 \\
\hline GCAAT & ATTGC & 969 & 16 & 1.651186791 \\
\hline GCCAT & ATGGC & 1278 & 28 & 2.190923318 \\
\hline CGAAG & CTTCG & 454 & 17 & 3.744493392 \\
\hline TCAAG & CTTGA & 560 & 9 & 1.607142857 \\
\hline GTAAA & TTTAC & 959 & 25 & 2.606882169 \\
\hline GTAAC & GTTAC & 1080 & 33 & 3.055555556 \\
\hline GTAAG & CTTAC & 552 & 13 & 2.355072464 \\
\hline AAGAG & СТСТT & 230 & 2 & 0.869565217 \\
\hline GCAAG & CTTGC & 613 & 19 & 3.099510604 \\
\hline GCAAA & TTTGC & 1143 & 36 & 3.149606299 \\
\hline GCAAC & GTTGC & 1249 & 25 & 2.001601281 \\
\hline AGGAG & СТССТ & 232 & 14 & 6.034482759 \\
\hline AGGAA & TTCCT & 482 & 18 & 3.734439834 \\
\hline AGCAG & CTGCT & 542 & 23 & 4.243542435 \\
\hline AGGAC & GTCCT & 613 & 12 & 1.957585644 \\
\hline CTCAC & GTGAG & 1343 & 39 & 2.903946389 \\
\hline TCTAC & GTAGA & 458 & 18 & 3.930131004 \\
\hline TCTAA & TTAGA & 644 & 11 & 1.708074534 \\
\hline TAGAG & CTCTA & 139 & 0 & 0 \\
\hline TCTAG & CTAGA & 395 & 5 & 1.265822785 \\
\hline TAAAA & TTTTA & 631 & 20 & 3.169572108 \\
\hline TAAAC & GTTTA & 552 & 15 & 2.717391304 \\
\hline AGGAT & ATCCT & 452 & 13 & 2.876106195 \\
\hline
\end{tabular}




\begin{tabular}{|c|c|c|c|c|}
\hline CTCAA & TTGAG & 1453 & 39 & 2.684101858 \\
\hline TCGAT & ATCGA & 255 & 10 & 3.921568627 \\
\hline TAAAT & ATTTA & 457 & 14 & 3.06345733 \\
\hline ACTAG & CTAGT & 649 & 30 & 4.622496148 \\
\hline ACAAC & GTTGT & 1433 & 42 & 2.930914166 \\
\hline ACAAA & TTTGT & 1320 & 44 & 3.333333333 \\
\hline ACAAG & CTTGT & 690 & 28 & 4.057971014 \\
\hline CAGAT & ATCTG & 904 & 16 & 1.769911504 \\
\hline GTTAA & TTAAC & 1008 & 18 & 1.785714286 \\
\hline GTTAC & GTAAC & 792 & 6 & 0.757575758 \\
\hline GCTAG & CTAGC & 597 & 13 & 2.177554439 \\
\hline GCTAA & TTAGC & 1029 & 13 & 1.263362488 \\
\hline GTTAG & CTAAC & 589 & 7 & 1.188455008 \\
\hline GCTAC & GTAGC & 774 & 19 & 2.454780362 \\
\hline CAGAA & TTCTG & 934 & 16 & 1.713062099 \\
\hline CAGAC & GTCTG & 1072 & 19 & 1.77238806 \\
\hline GTGAA & TTCAC & 867 & 14 & 1.614763552 \\
\hline ATTAA & TTAAT & 997 & 23 & 2.306920762 \\
\hline GGTAC & GTACC & 595 & 9 & 1.512605042 \\
\hline CAGAG & СTCTG & 455 & 10 & 2.197802198 \\
\hline ACAAT & ATTGT & 1185 & 42 & 3.544303797 \\
\hline GCTAT & ATAGC & 557 & 9 & 1.615798923 \\
\hline TCAAC & GTTGA & 869 & 31 & 3.567318757 \\
\hline TCAAA & TTTGA & 998 & 18 & 1.803607214 \\
\hline GTTAT & ATAAC & 681 & 7 & 1.027900147 \\
\hline ATTAC & GTAAT & 771 & 22 & 2.853437095 \\
\hline GGAAA & TTTCC & 576 & 16 & 2.777777778 \\
\hline TCAAT & ATTGA & 541 & 17 & 3.14232902 \\
\hline CCAAC & GTTGG & 1931 & 62 & 3.210771621 \\
\hline CCCAT & ATGGG & 2154 & 52 & 2.414113278 \\
\hline ACTAC & GTAGT & 1034 & 24 & 2.321083172 \\
\hline TTCAA & TTGAA & 849 & 22 & 2.591283863 \\
\hline \multirow[t]{2}{*}{ GTGAT } & ATCAC & 690 & 11 & 1.594202899 \\
\hline & & 212757 & 5148 & \\
\hline
\end{tabular}




\section{Codon frequency analysis}

a

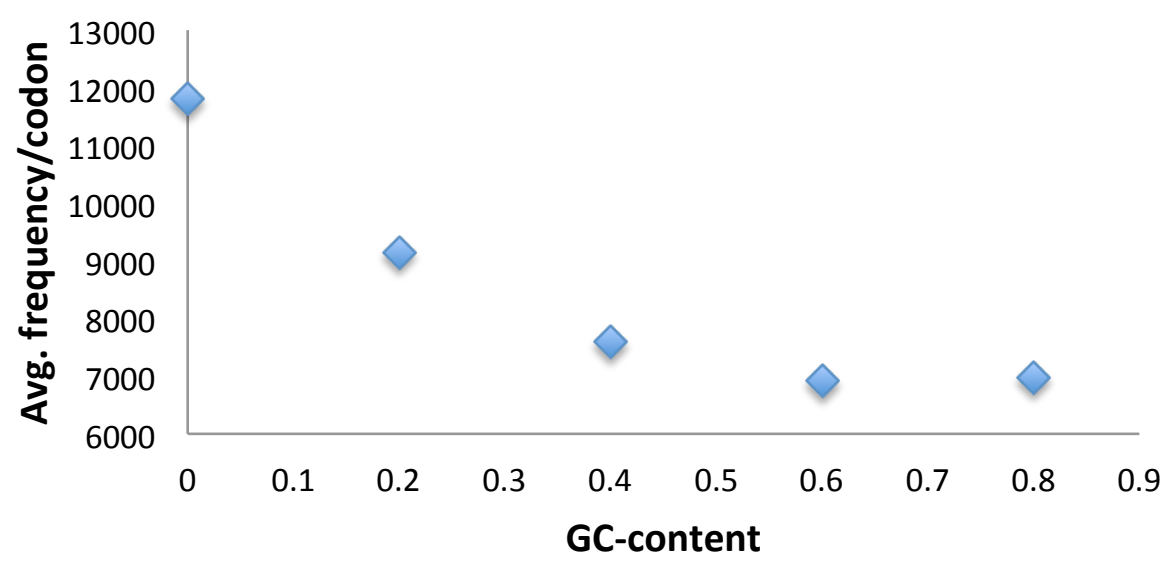

b

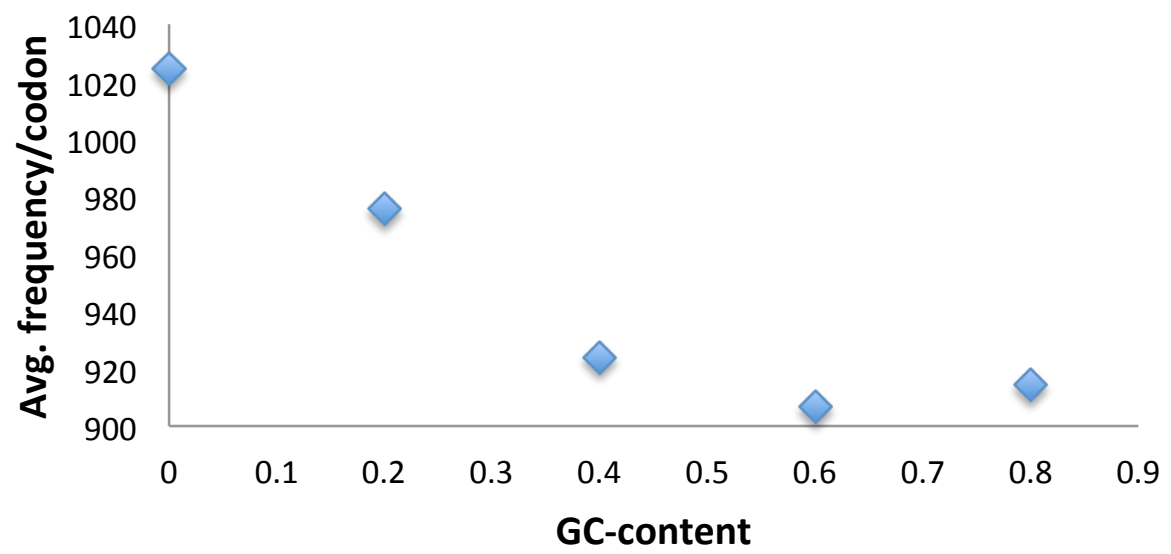

C

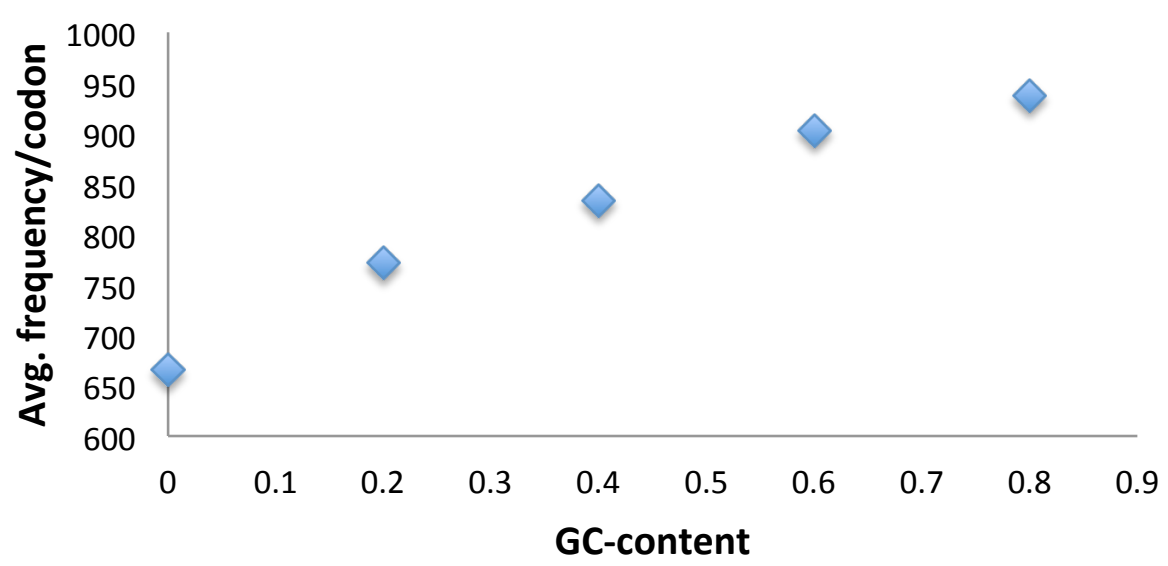

Figure S5. Influence of GC-content on codon bias during pentanucleotide polymerization using a) NNNAN b) $\operatorname{NNNA}\left(\mathrm{NH}_{2}\right) \mathrm{N}$ and c) NNNA(NHAc)N. 